\title{
Freshwater fish fauna of rivers of the southern Western Ghats, India
}

\author{
Anbu Aravazhi Arunkumar ${ }^{1}$ and Arunachalam Manimekalan ${ }^{2}$ \\ ${ }^{1}$ Department of Biotechnology, Karpagam Academy of Higher Education, \\ Coimbatore 641021, Tamil Nadu, India \\ ${ }^{2}$ Biodiversity and Molecular Lab, Department of Environmental Sciences, Bharathiar University, \\ Coimbatore 641046, Tamil Nadu, India
}

Correspondence: Anbu Aravazhi Arunkumar (anbu.arunkumar@gmail.com)

Received: 22 October 2017 - Discussion started: 1 November 2017

Revised: 4 August 2018 - Accepted: 11 August 2018 - Published: 28 September 2018

\begin{abstract}
The Western Ghats of India is a UNESCO World Heritage Site and is one of the eight "hotspots" of biological diversity in the world. It is also referred to as the "Great Escarpment of India". This paper provides information on the diversity of freshwater fish fauna of six river systems of the southern Western Ghats. The study area has been identified geographically using a GPS, and the respective topographic map has been digitized using ArcGIS software. The fish fauna were collected from various streams and rivers using cast nets, dip nets, gill nets and drag nets. Among the 31 georeferenced sites sampled from the rivers of the southern Western Ghats, a total of 64 species, belonging to 6 orders, 14 families and 31 genera, were recorded. Among them, the order Cypriniformes was dominant, with 3 families, 18 genera and 49 species $(76.6 \%)$. Principal component analysis and cluster analysis were performed to express the contribution of the variables and their influence on the species diversity. Interestingly, of the 31 sites, Thunakadavu stream, Gulithuraipatti, Athirapally, Naduthotam, Nadathittu, Mullaithodu, Thonanthikla, Noolpuzha and Sinnaru exhibited high variation in species diversity. Nearly 15 species were found to be threatened in the Western Ghats. Garra periyarensis and Cirrhinus cirrhosus are known to be vulnerable and Hemibagrus punctatus is critically endangered because of various anthropogenic activities. The study clearly indicates that certain timely measures have to be taken immediately to protect the fish fauna in the southern Western Ghats (https://doi.org/10.1594/PANGAEA.882214).
\end{abstract}

\section{Introduction}

The Western Ghats of India is a UNESCO World Heritage Site and is one of the eight "hotspots" of biological diversity in the world. It is also known as the "Great Escarpment of India" (Myers et al., 2000). The range of the Western Ghats runs from north to south along the western edge of the Deccan Plateau, and separates the plateau from a narrow coastal plain, called Konkan, along the Arabian Sea (Fig. 1, Bhavani river system). Of a total of 39 World Heritage Sites in India, which include national parks, wildlife sanctuaries and reserve forests, 20 are in Kerala, 10 in Karnataka, 5 in Tamil Nadu and 4 in Maharashtra; these have to be protected and conserved. The Western Ghats of India has rich freshwater fish fauna with a high level of endemism (Dahanukar et al., 2004). At present, a major part of the faunal diversity of the Western Ghats is threatened by human activities and invasive species (Dahanukar et al., 2004). Hence, knowledge of the diversity and distribution of the fish fauna is essential for designing and implementing conservation strategies. However, data on the fish fauna of the Western Ghats have limitations as most of the rivers have not been surveyed extensively with georeferenced data, and checklists for individual rivers are not available.

The history of Indian freshwater fish fauna goes back to Hamilton (1822), who studied fish fauna found in the river Ganges and its tributaries. Documentation and listing of fish fauna from different parts of India was mainly carried out by Jerdon (1848). A comprehensive and authori- 

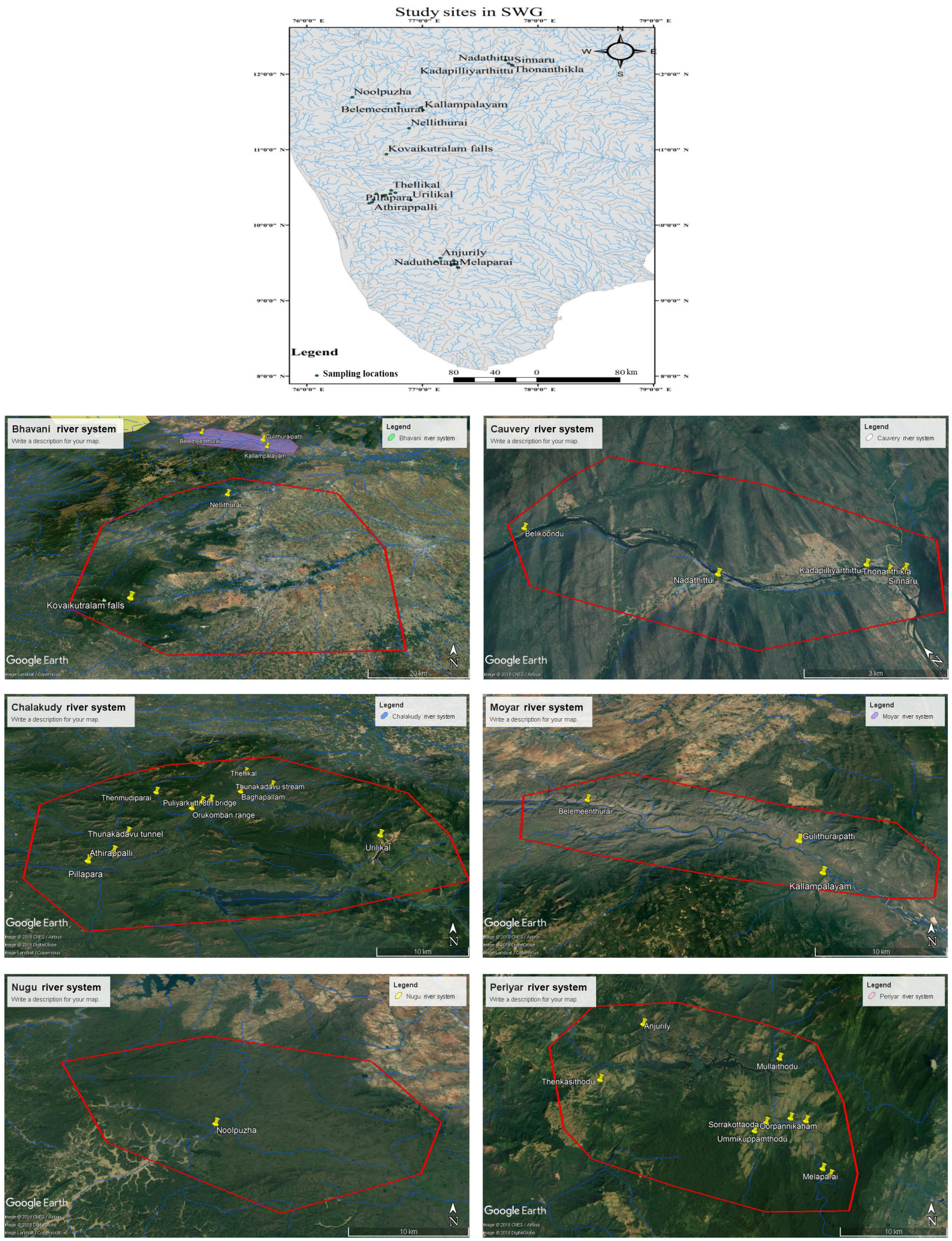

Figure 1. Location of collection sites in six river systems. 
tative account on the freshwater fish fauna has been provided by Day $(1865,1871,1878)$. Further investigations on the freshwater fish fauna of India, especially in the Western Ghats, were initiated by Hora (1921, 1937, 1941, 1949) and Hora and Misra (1938), and Hora also enunciated the Satpura Hypothesis. Silas (1951) listed 25 fish species from the Anamalai Hills and 10 species from the Nelliampathi Hills. His study extended the distribution of several species earlier known only from the central division of the Western Ghats to the southern division beyond the Palghat Gap. These led to new descriptions, initiating elaborate discussions on the endemism and other zoogeographical relevance of the area, and several new taxa were added from Kerala during this period. Studies on the endemic fish fauna from various streams and rivers in the Western Ghats mountain range have been compiled. Fish diversity in selected streams in northern Karnataka (Arunachalam et al., 1997) and the central Western Ghats (Arunachalam et al., 2000) has been reported. Manimekalan and Das (1998) described a new species, Glyptothorax davissinghi(Pisces: Sisoridae), a new catfish from Nilambur in the Nilgiri Biosphere, South India. Manimekalan and Singh (1997) made a new record of Schismatorhynchus (Nukta) nukta (Sykes) (Pisces: Cyprinidae) from Moyar River. Arunachalam et al. (2005) reported a new fish species, Neolissochilus wynaadensis, from the Karnataka part of the Western Ghats. Arunachalam et al. (2007) reported Psilorhynchus amplicephalus, a new species from Balishwar River, Assam, India. Earlier Biju et al. (1996) recorded Puntius filamentosus (Val.) and Puntius melanampyx (Day) in Orukomban and Thelikal during a survey from December 1996 to May 1997. Manimekalan and Arunachalam (2002) rediscovered the critically endangered air-breathing catfish Clarias dayi Hora (Pisces: Claridae) in Mudumalai Wildlife Sanctuary. Recently Arunkumar et al. (2015) reported nearly 37 species in the Cauvery river system. Considering the above facts, the present work documents freshwater fish fauna of the southern Western Ghats, especially from the Bhavani river system, Moyar river system, Chalakudy river system, Periyar river system, Cauvery river system and Nugu river system.

\section{Methodology}

\subsection{Collection and identification}

The study area has been identified geographically (the latitude and longitude coordinates) using a GPS, and the respective topographic map has been georeferenced and digitized using ArcGIS 9.3 version software. Fish fauna were collected using cast nets, dip nets, drag nets and gill nets of different mesh sizes ranging from 8 to $22 \mathrm{~mm}$. Proper care was taken to avoid damage to the specimens during collection. A total of five specimens from each species were collected from the georeferenced sampling locations, and fish fauna were photographed before being preserved in formalin so that they could be photographed in their original colour. Further, for smaller samples, specimens were preserved in $10 \%$ formalin, and for larger samples, formalin was injected into the abdominal cavity so that the internal organs could be preserved well for further taxonomic studies. The specimens were tagged, reference numbers were given for specimen identification, and they were transported to the lab. The species were identified based on the key given by Talwar and Jhingran (1991), Menon and Devi (1992) and Jayaram (1999, 2010). The holotype and paratype species were examined at the Zoological Survey of India (Chennai and Kolkata) for species confirmation. Voucher specimens were made for each species and were deposited at the Biodiversity and Molecular Lab, Dept. of Environmental Sciences, Bharathiar University, Coimbatore, Tamil Nadu, India.

\subsection{Physico-chemical analysis of the water quality at sampling sites}

Water samples were collected from all the sampling stations during the post-monsoon period (February to June) at a depth of $10 \mathrm{~cm}$. Water quality analyses such as $\mathrm{pH}$, conductivity, turbidity, total dissolved solids (TDS), resistivity, salinity, dissolved oxygen (DO), and water temperature were done as per the regulations of APHA (1995). Field analysis of the samples was done using a portable water analyzer ( $\mathrm{X}$ tech, Nagman Instruments Electronics, India) (Gurumurthy and Tripti, 2015; Thomas et al., 2015; Anushiya and Ramachandran, 2015).

\subsection{Analysis}

To quantify species diversity, a number of indices were applied. To measure the species diversity $\left(H^{\prime}\right)$ the most widely used Shannon index (Shannon and Weaver, 1949), Pielou's evenness index $(E)$ (Pielou, 1975) and Simpson's dominance index $(D)$ (Simpson, 1949) were used. Similarity coefficients of the fish community were calculated using the Jaccard index (Southwood, 1978). The species abundance and their relative frequencies were subjected to cluster analysis; a complete linkage cluster dendrogram was drawn based on the Pearson correlation. The contribution of the variables and their influence on the species diversity has been analysed using principal component analysis (Wills, 2005). The above statistical analyses were performed using SPSS (version 21), XLSTAT and Biodiversity Pro software.

\section{Results and discussion}

The fish fauna were surveyed from the streams and rivers of the southern Western Ghats. The collection sites were selected based on the earlier faunal distribution published in literature. The Western Ghats is a mountain range that runs almost parallel to the western coast of the Indian peninsula. 
Table 1. Study site and their habitat characteristics.

\begin{tabular}{|c|c|c|c|c|c|c|c|c|c|c|c|}
\hline \multirow[t]{2}{*}{$\begin{array}{l}\text { Site } \\
\text { number }\end{array}$} & \multirow[t]{2}{*}{ Study site } & Latitude & Longitude & Altitude & \multirow[t]{2}{*}{$\begin{array}{l}\text { Forest type } \\
\text { in tropical } \\
\text { region }\end{array}$} & \multirow[t]{2}{*}{$\begin{array}{c}\text { Stream } \\
\text { order }\end{array}$} & \multirow[t]{2}{*}{$\begin{array}{r}\text { Stream } \\
\text { width } \\
(\mathrm{m})\end{array}$} & \multirow[t]{2}{*}{$\begin{array}{r}\text { Stream } \\
\text { depth } \\
(\mathrm{m})\end{array}$} & \multirow[t]{2}{*}{$\begin{array}{l}\text { Area } \\
\left(\mathrm{m}^{2}\right)\end{array}$} & \multirow[t]{2}{*}{$\begin{array}{r}\text { Volume } \\
\qquad\left(\mathrm{m}^{3}\right)\end{array}$} & \multirow[t]{2}{*}{$\begin{array}{c}\text { Mean } \\
\text { velocity* } \\
\left(\mathrm{ms}^{-1}\right)\end{array}$} \\
\hline & & \multicolumn{2}{|c|}{ WGS84 (Datum) } & & & & & & & & \\
\hline \multicolumn{12}{|c|}{ Moyar river system } \\
\hline 1 & Gulithuraipatti & $11^{\circ} 33^{\prime} 20.4984^{\prime \prime} \mathrm{N}$ & $76^{\circ} 59^{\prime} 16.1016^{\prime \prime} \mathrm{E}$ & 312 & Thorn forest & 4 & 10 & 6 & 1000 & 6000 & 4 \\
\hline 2 & Kallampalayam & $11^{\circ} 31^{\prime} 25.3992^{\prime \prime} \mathrm{N}$ & $77^{\circ} 0^{\prime} 16.4016^{\prime \prime} \mathrm{E}$ & 300 & Thorn forest & 4 & 13 & 8 & 1300 & 10400 & 4 \\
\hline 3 & Belemeenthurai & $11^{\circ} 36^{\prime} 39.9996^{\prime \prime} \mathrm{N}$ & $76^{\circ} 47^{\prime} 38.0004^{\prime \prime} \mathrm{E}$ & 520 & Dry deciduous & 4 & 19 & 1.75 & 1900 & 3325 & 4 \\
\hline \multicolumn{12}{|c|}{ Chalakudy river system } \\
\hline 4 & Orukomban range & $10^{\circ} 22^{\prime} 53.6016^{\prime \prime} \mathrm{N}$ & $76^{\circ} 39^{\prime} 21.3984^{\prime \prime} \mathrm{E}$ & 450 & Dry deciduous & 4 & 6 & 0.5 & 600 & 300 & 3 \\
\hline 5 & Thenmudiparai & $10^{\circ} 24^{\prime} 51.9984^{\prime \prime} \mathrm{N}$ & $76^{\circ} 36^{\prime} 10.5012^{\prime \prime} \mathrm{E}$ & 510 & Dry deciduous & 5 & 25 & 1.5 & 2500 & 3750 & 3 \\
\hline 6 & Baghapallam & $10^{\circ} 24^{\prime} 57.6^{\prime \prime} \mathrm{N}$ & $76^{\circ} 43^{\prime} 21.3996^{\prime \prime} \mathrm{E}$ & 748 & Dry deciduous & 5 & 8 & 0.5 & 800 & 400 & 3 \\
\hline 7 & Thellikal & $10^{\circ} 27^{\prime} 34.2^{\prime \prime} \mathrm{N}$ & $76^{\circ} 43^{\prime} 48.7992^{\prime \prime} \mathrm{E}$ & 840 & Dry deciduous & 4 & 4 & 1.0 & 400 & 400 & 3 \\
\hline 8 & Puliyarkutti 8th bridge & $10^{\circ} 23^{\prime} 39.6996^{\prime \prime} \mathrm{N}$ & $76^{\circ} 40^{\prime} 8.1984^{\prime \prime} \mathrm{E}$ & 527 & Dry deciduous & 4 & 19.2 & 1.2 & 1920 & 2304 & 3 \\
\hline 9 & Puliyarkutti 3rd bridge & $10^{\circ} 23^{\prime} 52.5984^{\prime \prime} \mathrm{N}$ & $76^{\circ} 40^{\prime} 51.3012^{\prime \prime} \mathrm{E}$ & 512 & Dry deciduous & 4 & 37 & 1.5 & 3700 & 5550 & 3 \\
\hline 10 & Thunakadavu stream & $10^{\circ} 25^{\prime} 44.1012^{\prime \prime} \mathrm{N}$ & $76^{\circ} 46^{\prime} 4.6992^{\prime \prime} \mathrm{E}$ & 510 & Dry deciduous & 4 & 13.6 & 0.5 & 1360 & 680 & 3 \\
\hline 11 & Thunakadavu tunnel & $10^{\circ} 20^{\prime} 9.3012^{\prime \prime} \mathrm{N}$ & $76^{\circ} 34^{\prime} 40.6992^{\prime \prime} \mathrm{E}$ & 520 & Dry deciduous & 5 & 15 & 10 & 1500 & 15000 & 5 \\
\hline 12 & Urilikal & $10^{\circ} 19^{\prime} 54.1992^{\prime \prime} \mathrm{N}$ & $76^{\circ} 53^{\prime} 57.3^{\prime \prime} \mathrm{E}$ & 3238 & Dry deciduous & 2 & 7 & 1.5 & 700 & 1050 & 2 \\
\hline 13 & Athirappilly & $10^{\circ} 18^{\prime} 15.3598^{\prime \prime} \mathrm{N}$ & $76^{\circ} 34^{\prime} 0.0012^{\prime \prime} \mathrm{E}$ & 202 & Semi-evergreen & 4 & 8 & 3 & 800 & 2400 & 4 \\
\hline 14 & Pillapara & $10^{\circ} 17^{\prime} 23.82^{\prime \prime} \mathrm{N}$ & $76^{\circ} 32^{\prime} 21.84^{\prime \prime} \mathrm{E}$ & 267 & Semi-evergreen & 4 & 5 & 2 & 500 & 1000 & 4 \\
\hline \multicolumn{12}{|c|}{ Bhavani river system } \\
\hline 15 & Kovaikutralam falls & $10^{\circ} 56^{\prime} 20.1516^{\prime \prime} \mathrm{N}$ & $76^{\circ} 41^{\prime} 21.0084^{\prime \prime} \mathrm{E}$ & 560 & Semi-evergreen & 2 & 5 & 1.2 & 500 & 600 & 4 \\
\hline 16 & Nellithurai & $11^{\circ} 17^{\prime} 0.3012^{\prime \prime} \mathrm{N}$ & $76^{\circ} 53^{\prime} 6.9^{\prime \prime} \mathrm{E}$ & 380 & Thorn forest & 4 & 27 & 1.1 & 2700 & 2970 & 5 \\
\hline \multicolumn{12}{|c|}{ Periyar river system } \\
\hline 17 & Oorpannikaham & $9^{\circ} 28^{\prime} 58.1016^{\prime \prime} \mathrm{N}$ & $77^{\circ} 16^{\prime} 47.7012^{\prime \prime} \mathrm{E}$ & 884 & Evergreen & 4 & 12 & 2.1 & 1200 & 2520 & 2 \\
\hline 18 & Valukuparai & $9^{\circ} 28^{\prime} 49.4004^{\prime \prime} \mathrm{N}$ & $77^{\circ} 17^{\prime} 35.0988^{\prime \prime} \mathrm{E}$ & 869 & Evergreen & 4 & 7.5 & 0.3 & 750 & 225 & 3 \\
\hline 19 & Melaparai & $9^{\circ} 26^{\prime} 24.7992^{\prime \prime} \mathrm{N}$ & $77^{\circ} 18^{\prime} 24.5988^{\prime \prime} \mathrm{E}$ & 965 & Evergreen & 4 & 11 & 4.2 & 1100 & 4620 & 3 \\
\hline 20 & Naduthotam & $9^{\circ} 26^{\prime} 5.1^{\prime \prime} \mathrm{N}$ & $77^{\circ} 18^{\prime} 48.0996^{\prime \prime} \mathrm{E}$ & 950 & Evergreen & 4 & 7.5 & 0.3 & 750 & 225 & 3 \\
\hline 21 & Ummikuppamthodu & $9^{\circ} 28^{\prime} 20.6004^{\prime \prime} \mathrm{N}$ & $77^{\circ} 14^{\prime} 57.0984^{\prime \prime} \mathrm{E}$ & 943 & Evergreen & 4 & 5 & 3.0 & 500 & 1500 & 4 \\
\hline 22 & Sorrakottaodai & $9^{\circ} 28^{\prime} 45.4008^{\prime \prime} \mathrm{N}$ & $77^{\circ} 15^{\prime} 32.7996^{\prime \prime} \mathrm{E}$ & 879 & Evergreen & 4 & 7 & 1.5 & 700 & 1050 & 3 \\
\hline 23 & Mullaithodu & $9^{\circ} 31^{\prime} 58.6992^{\prime \prime} \mathrm{N}$ & $77^{\circ} 16^{\prime} 15.8016^{\prime \prime} \mathrm{E}$ & 869 & Evergreen & 4 & 10 & 0.6 & 1000 & 600 & 3 \\
\hline 24 & Anjurily & $9^{\circ} 33^{\prime} 46.1988^{\prime \prime} \mathrm{N}$ & $77^{\circ} 9^{\prime} 19.6992^{\prime \prime} \mathrm{E}$ & 912 & Evergreen & 4 & 20 & 5 & 2000 & 10000 & 2 \\
\hline 25 & Thenkasithodu & $9^{\circ} 30^{\prime} 59.4^{\prime \prime} \mathrm{N}$ & $77^{\circ} 7^{\prime} 5.9988^{\prime \prime} \mathrm{E}$ & 872 & Evergreen & 4 & 11.3 & 0.5 & 1130 & 565 & 2 \\
\hline \multicolumn{12}{|c|}{ Cauvery river system } \\
\hline 26 & Kadapilliyarthittu & $12^{\circ} 7^{\prime} 18.1992^{\prime \prime} \mathrm{N}$ & $77^{\circ} 46^{\prime} 28.3008^{\prime \prime} \mathrm{E}$ & 1137 & Dry deciduous & 4 & 75 & 1.5 & 7500 & 11250 & 2 \\
\hline 27 & Belikoondu & $12^{\circ} 11^{\prime} 2.1012^{\prime \prime} \mathrm{N}$ & $77^{\circ} 43^{\prime} 12.6012^{\prime \prime} \mathrm{E}$ & 267 & Dry deciduous & 4 & 80 & 10 & 8000 & 80000 & 5 \\
\hline 28 & Nadathittu & $12^{\circ} 8^{\prime} 31.9992^{\prime \prime} \mathrm{N}$ & $77^{\circ} 44^{\prime} 48.9984^{\prime \prime} \mathrm{E}$ & 262 & Dry deciduous & 4 & 70 & 6 & 7000 & 42000 & 3 \\
\hline 29 & Sinnaru & $12^{\circ} 6^{\prime} 54.7992^{\prime \prime} \mathrm{N}$ & $77^{\circ} 46^{\prime} 48.5004^{\prime \prime} \mathrm{E}$ & 225 & Dry deciduous & 4 & 55 & 0.5 & 5500 & 2750 & 3 \\
\hline 30 & Thonanthikla & $12^{\circ} 7^{\prime} 2.3988^{\prime \prime} \mathrm{N}$ & $77^{\circ} 46^{\prime} 36.6996^{\prime \prime} \mathrm{E}$ & 341 & Dry deciduous & 4 & 25 & 1 & 2500 & 2500 & 4 \\
\hline \multicolumn{12}{|c|}{ Nugu river system } \\
\hline 31 & Noolpuzha & $11^{\circ} 41^{\prime} 35.0988^{\prime \prime} \mathrm{N}$ & $76^{\circ} 23^{\prime} 36.3984^{\prime \prime} \mathrm{E}$ & 2810 & Semi-evergreen & 3 & 25 & 4.1 & 2500 & 10250 & 4 \\
\hline
\end{tabular}

Velocity $\left(\mathrm{m} \mathrm{s}^{-1}\right)$ : 1 . very slow $(<0.05) ; 2$. slow $(0.05-0.2) ; 3$. moderate $(0.2-0.5) ; 4$. fast $(0.5-1.0) ; 5$. very fast $(>1)$.

The study sites and their characteristics are recorded and presented in Table 1 and Fig. 1. In the present work, a total of 31 sites of six river systems of the southern Western Ghats were studied, of which a total of 64 species, belonging to 6 orders, 14 families and 31 genera, were recorded (Table 2). Among them, the order Cypriniformes was dominant, with 3 families, 18 genera and 49 species $(76.6 \%)$, compared to other orders (Figs. 2, 7).

\subsection{Fish species diversity, abundance, and distribution}

Among the 31 sampling locations, high species diversity was recorded at Sinnaru of the Cauvery river system $\left(H^{\prime}=\right.$ 1.268) and low diversity was recorded at Thunakadavu tunnel of the Chalakudy river system $\left(H^{\prime}=0.357\right)$ (Table 3,
Fig. 3). The maximum species diversity was recorded at Sinnaru of the Cauvery river system $(S=21)$, and the minimum was recorded at Puliyarkutti 3rd bridge and Thunakadavu tunnel of the Chalakudy river system and Sorrakottaodai of the Periyar river system $(S=3)$ (Table 3, Fig. 4). The maximum species abundance, 152, was recorded at Naduthottam of the Periyar river system, and the lowest, 16, was recorded at Sorrakottaodai of the Periyar river system and Belikoondu of the Cauvery river system (Table 3, Fig. 5). The maximum dominance index $(D=21.346)$ was recorded at Sinnaru of the Cauvery river system, and the lowest $(D=2.121)$ was recorded at Thunakadavu tunnel of the Chalakudy river system (Table 3). 
Table 2. List of freshwater fauna recorded during the present study.

\begin{tabular}{|c|c|c|c|}
\hline S. no & Species & $\begin{array}{r}\text { Distribution } \\
\text { locations }\end{array}$ & IUCN \\
\hline & $\begin{array}{l}\text { Order: Cypriniformes } \\
\text { Family: Cyprinidae } \\
\text { Subfamily: Cyprininae }\end{array}$ & & \\
\hline 1 & Puntius melanampyx & 18 & DD \\
\hline 2 & Puntius carnaticus & 10 & $\mathrm{LC}$ \\
\hline 3 & Puntius amphibius & 4 & DD \\
\hline 4 & Haludaria fasciatus & 11 & $\mathrm{LC}$ \\
\hline 5 & Dawkinsia filamentosa & 4 & $\mathrm{LC}$ \\
\hline 6 & Puntius sarana sarana & 4 & $\mathrm{LC}$ \\
\hline 7 & Puntius dorsalis & 2 & $\mathrm{LC}$ \\
\hline 8 & Puntius chola & 2 & $\mathrm{LC}$ \\
\hline 9 & Puntius sophore & 1 & $\mathrm{LC}$ \\
\hline 10 & Eechathalakenda ophicephalus & 2 & EN \\
\hline 11 & Puntius mahecola & 7 & DD \\
\hline 12 & Pethia conchonius & 4 & $\mathrm{LC}$ \\
\hline 13 & Sahyadria denisonii & 2 & EN \\
\hline 14 & Sahyadria chalakkudiensis & 2 & EN \\
\hline 15 & Puntius sarana spirulus & 1 & $\mathrm{LC}$ \\
\hline 16 & Puntius bimaculatus & 3 & $\mathrm{LC}$ \\
\hline 17 & Pethia ticto & 1 & $\mathrm{LC}$ \\
\hline 18 & Cirrhinus cirrhosus & 2 & VU \\
\hline 19 & Skymatorynchus nukta & 3 & EN \\
\hline 20 & Labeo boggut & 1 & $\mathrm{LC}$ \\
\hline 21 & Labeo kontius & 1 & $\mathrm{LC}$ \\
\hline 22 & Labeo ariza & 3 & LC \\
\hline 23 & Labeo calbasu & 2 & LC \\
\hline 24 & Labeo boga & 2 & $\mathrm{LC}$ \\
\hline 25 & Hypselobarbus curтиса & 4 & EN \\
\hline 26 & Hypselobarbus periyarensis & 3 & EN \\
\hline 27 & Hypselobarbus dubius & 6 & $\mathrm{EN}$ \\
\hline 28 & Tor malabaricus & 5 & EN \\
\hline 29 & Tor khudree & 9 & EN \\
\hline \multirow[t]{2}{*}{30} & Osteochilus longidorsalis & 2 & EN \\
\hline & Subfamily: Danioninae & & \\
\hline 31 & Salmophasia acinaces & 1 & $\mathrm{LC}$ \\
\hline 32 & Barilius gatensis & 16 & $\mathrm{LC}$ \\
\hline 33 & Barilius bakeri & 10 & $\mathrm{LC}$ \\
\hline 34 & Barilius barana & 2 & $\mathrm{LC}$ \\
\hline 35 & Barilius bendelisis & 3 & $\mathrm{LC}$ \\
\hline 36 & Devario aequipinnatus & 21 & $\mathrm{LC}$ \\
\hline \multirow[t]{2}{*}{37} & Rasbora daniconius & 13 & $\mathrm{LC}$ \\
\hline & Subfamily: Oreininae & & \\
\hline \multirow[t]{2}{*}{38} & Lepiphygopsis typus & 2 & EN \\
\hline & Subfamily: Garrinae & & \\
\hline 39 & Garra mullya & 16 & $\mathrm{LC}$ \\
\hline 40 & Garra surendranathi & 3 & $\mathrm{EN}$ \\
\hline 41 & Garra nasuta & 1 & $\mathrm{LC}$ \\
\hline 42 & Garra periyarensis & 2 & VU \\
\hline 43 & Garra hughi & 3 & EN \\
\hline 44 & Garra gotyla stenorhynchus & 2 & $\mathrm{LC}$ \\
\hline \multirow[t]{2}{*}{45} & Crossocheilus latius latius & 1 & $\mathrm{LC}$ \\
\hline & $\begin{array}{l}\text { Family: Balitoridae } \\
\text { Subfamily: Balitorinae }\end{array}$ & & \\
\hline 46 & Travancoria jonesi & 8 & EN \\
\hline
\end{tabular}

Table 2. Continued.

\begin{tabular}{|c|c|c|c|}
\hline & Subfamily: Nemacheilinae & & \\
\hline 47 & Nemacheilus denisoni & 2 & LC \\
\hline \multirow[t]{3}{*}{48} & Nemacheilus guentheri & 7 & LC \\
\hline & Family: Cobitidae & & \\
\hline & Subfamily: Cobitinae & & \\
\hline \multirow[t]{4}{*}{49} & Lepidocephalus thermalis & 5 & $\mathrm{LC}$ \\
\hline & Order: Siluriformes & & \\
\hline & Family: Bagridae & & \\
\hline & Subfamily: Bagrinae & & \\
\hline 50 & Hemibagrus punctatus & 3 & $\mathrm{CR}$ \\
\hline \multirow[t]{2}{*}{51} & Mystus cavasius & 4 & $\mathrm{LC}$ \\
\hline & Family: Siluridae & & \\
\hline \multirow[t]{3}{*}{52} & Ompok bimaculatus & 1 & NT \\
\hline & Family: Sisoridae & & \\
\hline & Subfamily: Glyptosterninae & & \\
\hline \multirow[t]{4}{*}{53} & Glyptothorax housei & 1 & EN \\
\hline & Order: Cyprinodontiformes & & \\
\hline & Family: Aplocheilidae & & \\
\hline & Subfamily: Aplocheilinae & & \\
\hline \multirow[t]{5}{*}{54} & Aplocheilus lineatus & 3 & $\mathrm{LC}$ \\
\hline & Order: Synbranchiformes & & \\
\hline & Suborder: Mastacembeloidei & & \\
\hline & Family: Mastacembelidae & & \\
\hline & Subfamily: Mastacembelidae & & \\
\hline 55 & Macrognathus pancalus & 1 & LC \\
\hline 56 & Mastacembelus armatus & 1 & $\mathrm{LC}$ \\
\hline
\end{tabular}

Order: Perciformes

Suborder: Percoidei

Family: Ambassidae

\begin{tabular}{llcc}
\hline 57 & Chanda nama & 2 & LC \\
\hline \multicolumn{4}{c}{ Family: Pristolepididae } \\
\hline 58 & Peristolepis marginata & 3 & LC \\
\hline & Suborder: Labroidei & & \\
& Family: Cichlidae & & \\
\hline 59 & Oreochromis mossambica & 1 & NT \\
60 & Etroplus suratensis & 3 & LC \\
61 & Etroplus maculatus & 2 & LC \\
\hline & Suborder: Gobioidei & & \\
& Family: Gobiidae & & \\
& Subfamily: Gobiinae & & \\
\hline 62 & Glossogobius guiris & 1 & LC \\
\hline & Order: Mugiliformes & & \\
& Suborder: Belonoidei & & \\
& Family: Belonidae & & \\
\hline 63 & Xenentodon cancila & 3 & LC \\
\hline & Family: Hemiramphidae & \\
\hline 64 & Hyporhamphus limbatus & 2 & LC \\
\hline * EX: extinct; EW: extinct in the wild; CR: critically & \\
endangered; EN: endangered; VU: vulnerable; NT: near \\
threatened; LC: least concern; LRlc: low risk, least concern; \\
LRcd: low risk, conservation-dependent; DD: data-deficient.
\end{tabular}


Table 3. Indices of diversity of fish fauna and respective altitudes of six river systems.

\begin{tabular}{|c|c|c|c|c|c|c|}
\hline Sampling locations & Altitude & Diversity $\left(H^{\prime}\right)$ & Evenness $(E)$ & Abundance & Richness $(S)$ & Dominance $(D)$ \\
\hline \multicolumn{7}{|l|}{ Moyar river system } \\
\hline Belemeenthurai & 520 & 0.841 & 0.932 & 19 & 8 & 8.55 \\
\hline Gulithuraipatti & 312 & 0.769 & 0.769 & 62 & 10 & 5.016 \\
\hline Kallampalayam & 300 & 0.62 & 0.686 & 38 & 8 & 3.316 \\
\hline \multicolumn{7}{|l|}{ Chalakudy river system } \\
\hline Urilikal & 3238 & 0.734 & 0.869 & 131 & 7 & 4.598 \\
\hline Thellikal & 840 & 0.805 & 0.843 & 32 & 9 & 5.701 \\
\hline Baghapallam & 748 & 0.617 & 0.793 & 36 & 6 & 3.728 \\
\hline Puliyarkutti 8th bridge & 527 & 0.879 & 0.921 & 39 & 9 & 7.8 \\
\hline Thunakadavu tunnel & 520 & 0.357 & 0.748 & 42 & 3 & 2.121 \\
\hline Puliyarkutti 3rd bridge & 512 & 0.401 & 0.841 & 17 & 3 & 2.429 \\
\hline Thunakadavu stream & 510 & 0.864 & 0.864 & 68 & 10 & 6.026 \\
\hline Thenmudiparai & 510 & 0.74 & 0.875 & 59 & 7 & 4.833 \\
\hline Orukomban range & 450 & 0.711 & 0.842 & 49 & 7 & 4.576 \\
\hline Pillapara & 267 & 0.718 & 0.923 & 25 & 6 & 5.769 \\
\hline Athirappilly & 202 & 1.01 & 0.936 & 52 & 12 & 11.143 \\
\hline \multicolumn{7}{|l|}{ Bhavani river system } \\
\hline Kovaikutralam falls & 560 & 0.722 & 0.928 & 40 & 6 & 5 \\
\hline Nellithurai & 380 & 0.757 & 0.896 & 29 & 7 & 5.639 \\
\hline \multicolumn{7}{|l|}{ Periyar river system } \\
\hline Melaparai & 965 & 0.798 & 0.944 & 19 & 7 & 7.773 \\
\hline Naduthotam & 950 & 1.019 & 0.915 & 152 & 13 & 9.936 \\
\hline Ummikuppamthodu & 943 & 0.527 & 0.678 & 41 & 6 & 2.384 \\
\hline Anjurily & 912 & 0.537 & 0.768 & 19 & 5 & 3.054 \\
\hline Oorpannikaham & 884 & 0.767 & 0.849 & 27 & 8 & 5.4 \\
\hline Sorrakottaodai & 879 & 0.465 & 0.976 & 16 & 3 & 3.243 \\
\hline Thenkasithodu & 872 & 0.638 & 0.668 & 100 & 9 & 3.327 \\
\hline Valukuparai & 869 & 0.91 & 0.954 & 28 & 9 & 9.947 \\
\hline Mullaithodu & 869 & 1.045 & 0.968 & 48 & 12 & 12.966 \\
\hline \multicolumn{7}{|l|}{ Cauvery river system } \\
\hline Kadapilliyarthittu & 1137 & 0.8 & 0.886 & 37 & 8 & 6.055 \\
\hline Thonanthikla & 341 & 1.069 & 0.909 & 46 & 15 & 11.129 \\
\hline Belikoondu & 267 & 0.625 & 0.804 & 16 & 6 & 3.75 \\
\hline Nadathittu & 262 & 1.198 & 0.921 & 77 & 20 & 15.481 \\
\hline Sinnaru & 225 & 1.268 & 0.959 & 75 & 21 & 21.346 \\
\hline \multicolumn{7}{|l|}{ Nugu river system } \\
\hline Noolpuzha & 2810 & 0.946 & 0.946 & 78 & 10 & 8.938 \\
\hline
\end{tabular}

\subsection{Species composition}

Species similarity between the sites was very low among 31 sites of six river systems. Cluster analysis exhibited similar species composition between the sites (Table 4, Fig. 6). A total of five clusters were grouped, which clearly demonstrate the similarity of species composition among the sites. The cluster group separation is based on the following reasons: (1) rare species forms, (2) low water temperature and (3) prevalence of human disturbances.

\subsection{Water quality}

Water quality parameters are recorded and presented in Table 6. It is found that the parameter values lie within the IS: 10500 Permissible limits (Table 6 of BIS, 2012). The selected sites of the Western Ghats has a water $\mathrm{pH}$ ranging from 6.5 to 8.5. A pH of 9 was recorded at Kadapilliyarthittu of the Cauvery river system, and 7.2 was recorded at various sites like Anjurily, Athirappilly and Urilikal. A minimum conductivity value of $27.8 \mathrm{mS}$ was recorded in the Chalakudy 


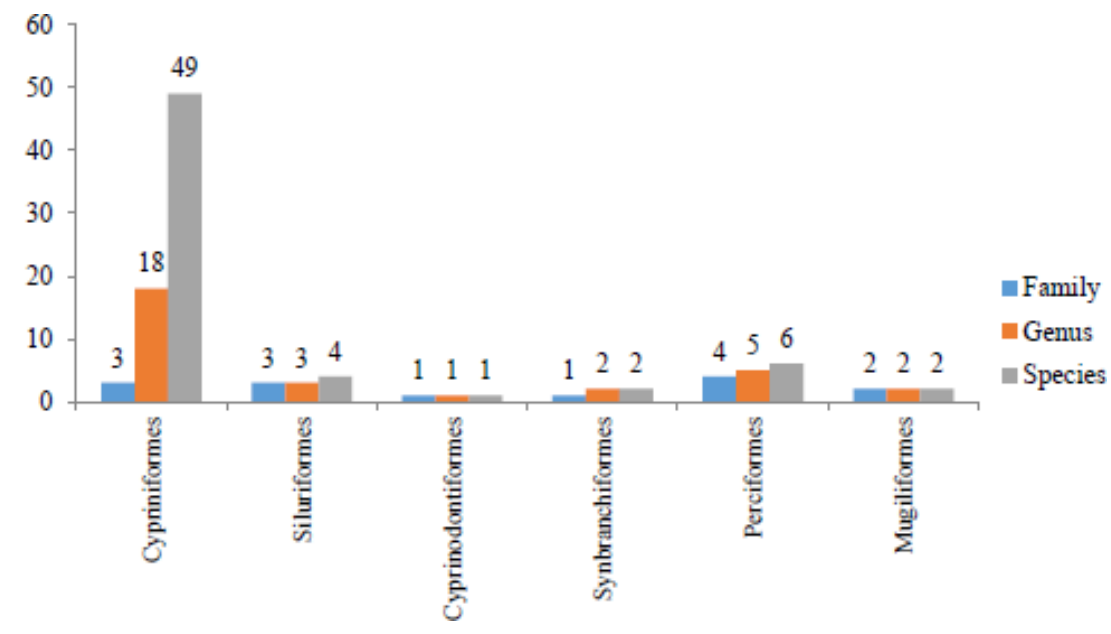

Figure 2. Representation of fish fauna orders among the six river systems.

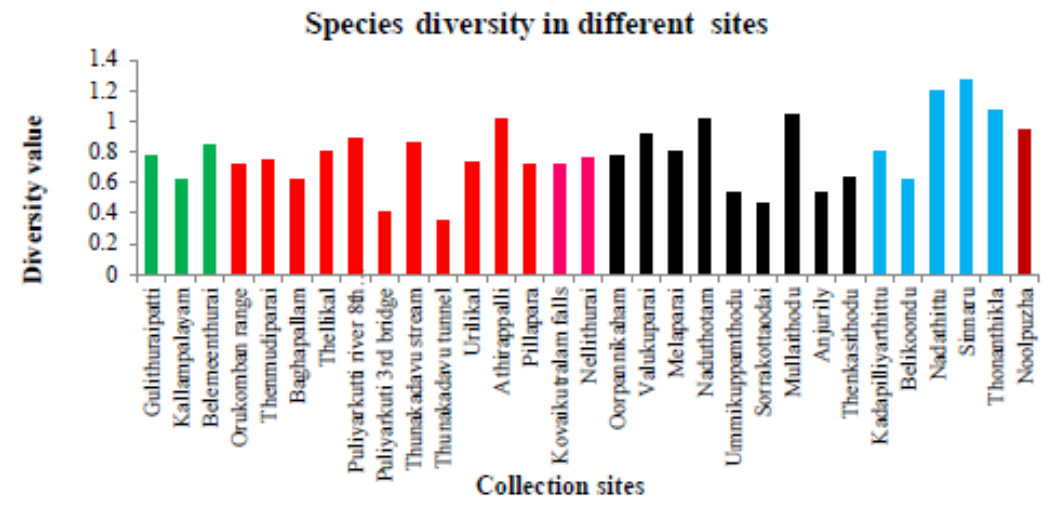

\begin{tabular}{|c|c|c|}
\hline Periyar river system & Moyar river system & Bhavani river system \\
\hline Cauvery river system & Chalakudy river system & Nugu river system \\
\hline
\end{tabular}

Figure 3. Species diversity among 31 sites.
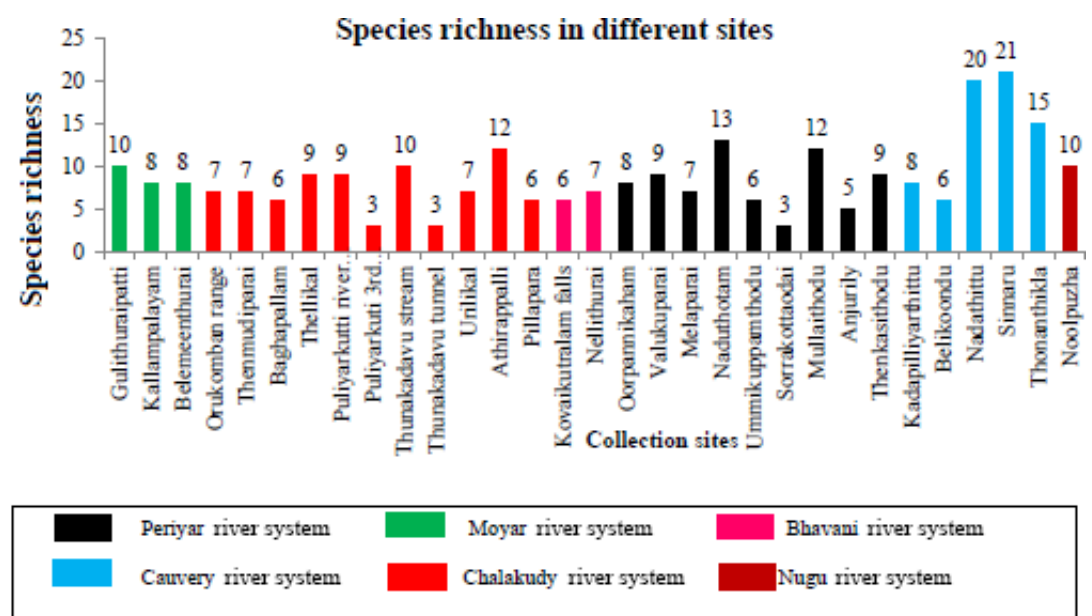

Figure 4. Species richness among 31 sites. 

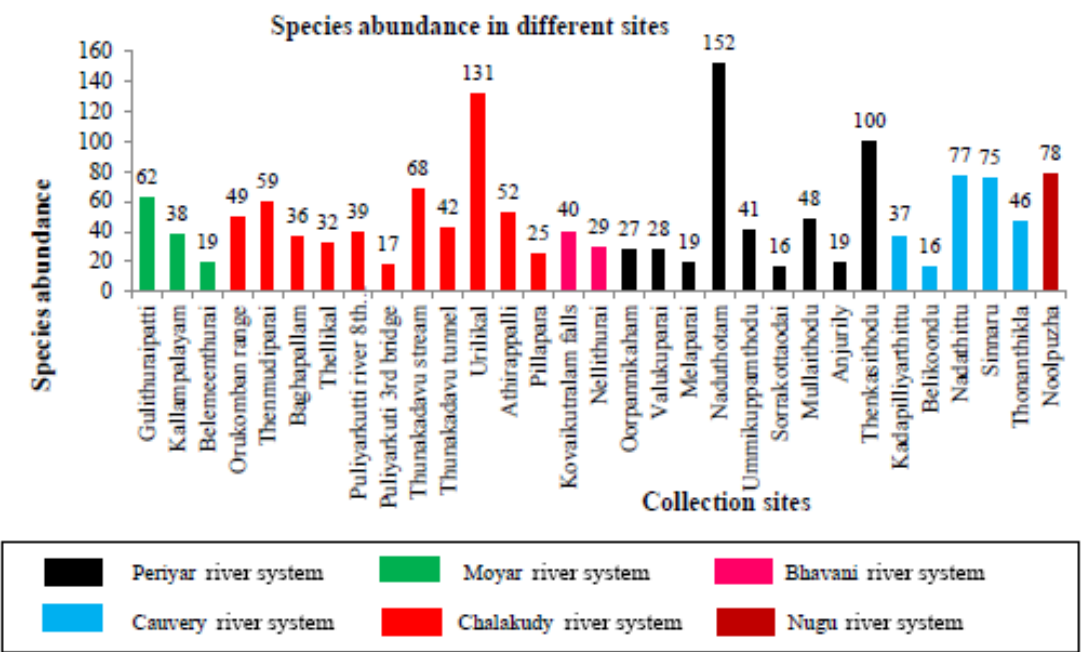

Figure 5. Species abundance among 31 sites.

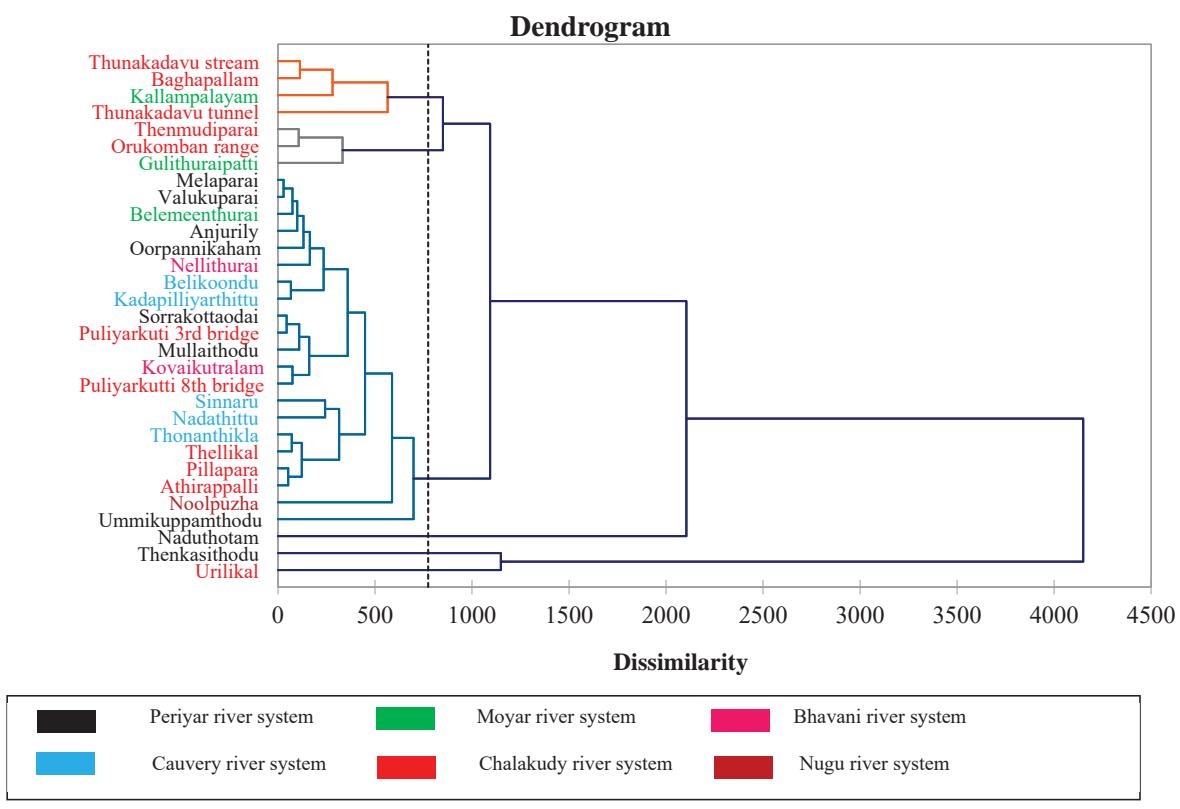

Figure 6. Cluster dendogram expressing the dissimilarity.

river system, and a maximum conductivity value of $85.2 \mathrm{mS}$ was recorded at Noolpuzha of the Nugu river system. Total dissolved solids (TDS) are a measure of inorganic salts dissolved in water. These dissolved solids come from both natural and human sources. Mitchell and Stapp (1992) have suggested that changes in TDS concentrations can be harmful. If TDS concentrations are too high or too low, the population of aquatic life can be limited. Thenkasithodu of the Periyar river system witnessed a low value of TDS content of $13.7 \mathrm{mg} \mathrm{L}^{-1}$, and at Urilikal of the Chalakudy river system, a high value of TDS of $51.9 \mathrm{mg} \mathrm{L}^{-1}$ was recorded. A minimum resistivity value of 2.58 was measured at Kadapilliyarthittu of the Cauvery river system, and a maximum of
45.6 was measured at Thenkasithodu of the Periyar river system. A high level of DO of $6.11 \mathrm{mg} \mathrm{L}^{-1}$ was recorded at Thenkasithodu of the Periyar river system, and a low DO of $0.63 \mathrm{mg} \mathrm{L}^{-1}$ was recorded at Belikoondu of the Cauvery river system. Arunkumar et al. (2015) posited that the lowest DO recorded at sampling sites is due to organic-rich domestic waste let into the river by tourists in the river system. A maximum water temperature $\left(33.6^{\circ} \mathrm{C}\right)$ was recorded at Pillapara of the Chalakudy river system, and a minimum water temperature $\left(18.9^{\circ} \mathrm{C}\right)$ was noted at Thenkasithodu of the Periyar river system. 


\subsection{Habitat structure}

Stream habitat was measured in dimensions like length, width, depth, substratum and current. Large proportions (> $50 \%)$ of the habitat sampled included very shallow water $(<1 \mathrm{~cm})$. Typically, such areas are not habitable for fish fauna and most fish are concentrated in dispersed pools, indicating that habitat measures in upstream areas should be restricted to the pools themselves (Gorman, 1978).

\subsection{Substratum types}

For the present study, the fish species diversity and the habitat quality assessments of the river systems have been considered as major criteria. The results exhibit that flora and fauna flourish in the study area. This proves that the habitat provides food and shelter suitable for the fish fauna and other aquatic organisms. The habitat assessment of the study area shows that there are four habitat types (pool, riffle, run and glide) with six substratum types (fine sand, debris, silt, bedrock, gravel, rubble and boulders). The shoreline also has a sandy border and a strong rigid bottom made up of rocks, which creates a good habitat for the aquatic organisms. Moreover the water quality, substratum type and vegetation provide a good and healthy habitat and high food resource availability, which plays a key role in species diversity. The river habitat is utilized by tribal people for catching fish for their source of protein food. In the present study, the substratum types of rubble and boulders were dominant, representing $80 \%$ in Mullaithodu of the Periyar river system. At Anjurily of the Periyar river system, gravel is the dominant substratum, representing $70 \%$. Moreover, substratum types like sand and silt are equally represented in all the study sites. Debris is the biological matter that occupies a major part the stream habitat and is important for providing good shelter and a feeding habitat for the fish fauna. Mostly bottom feeders like Garra, Nemacheilus and Travanchoria use these debris and bedrock substratum as their habitat in a total stream channel with all other substratum types. Nadathittu of Cauvery River, Naduthotam of the Periyar River, Kovaikutralam of Bhavani River and Thunakadavu of the Chalakudy river system have their base substratum as natural bedrock, which provides them with a strong rigid bottom.

Stream width and volume were high at Belikoondu of the Cauvery river system $\left(80 \mathrm{~m}, 80000 \mathrm{~m}^{3}\right)$, followed by Nadathittu $\left(70 \mathrm{~m}, 42000 \mathrm{~m}^{3}\right)$, Kadapilliyarthittu $\left(75 \mathrm{~m}, 11250 \mathrm{~m}^{3}\right)$, Kallampalayam $\left(13 \mathrm{~m}, 10400 \mathrm{~m}^{3}\right)$ and Noolpuzha $\left(25 \mathrm{~m}, 10250 \mathrm{~m}^{3}\right)$. The lowest stream width and volume were recorded at Thellikal $\left(4 \mathrm{~m}, 400 \mathrm{~m}^{3}\right)$. Among the 31 sites, very fast-flowing water was noted at Nellithurai, Thunakadavu tunnel and Belikoondu. Fast-flow water and moderate-flow water was noted in most of the river systems. A slow flow of water in the channels was recorded at Thenkasithodu, Kadapilliyarthittu, Oorpannikaham and Urilikal.

\subsection{Ecological structures influence characterization}

Principal component analysis was used to illustrate the influence of the variables and its importance for the ecological structure of the river system and the fish species. The various habitat characteristics, like water quality, channel morphology and the substratum type, influence the species distribution. Factors like altitude (6.940), area (21.449) and volume (58.428) influence the species diversity (Table 7). All other characteristics play a supportive role in expressing the variations among the study sites. Based on the contributions, study sites like Belikoondu, Kallampalayam, Sorrakottaodai, Anjurily, Thenkasithodu, Belemeenthurai, Kovaikutralam, Naduthotam, Nadathittu, Kadapilliyarthittu and Sinnaru exhibit more variations. The results obtained conclude that altitude plays a major role in species diversity and species abundance, which supports the proposed theory that diversity changes with altitude on mountainsides, being lowest at higher elevations (Colinvaux, 1930). The present findings support the above theory as the results express that species diversity and abundance are low at high altitudes. Among the 31 sites, high species diversity was recorded at Sinnaru of the Cauvery river system $\left(H^{\prime}=1.268\right)$ because of the altitude, area of the channel and the volume of flow as well. The maximum species diversity was recorded at Sinnaru of the Cauvery river system $(S=21)$, due to the channel flow, altitude and the submerged substratum types with muddy water flow. The maximum species abundance of 152 was recorded at Naduthotam of the Periyar river system due to the low area of the channel and the maximum percentage of the rocky boulder substratum. The maximum dominance of species $(D=21.34)$ was recorded at Sinnaru of the Cauvery river system influenced by the vast channel area. The rest of the sites showed low dominance due to the lower percentage of influence caused by the habitat structures.

Rajan (1955) studied the fish fauna from the Moyar river system and reported 48 species. Manimekalan (1998) reported 38 species in the Mudumalai wildlife sanctuary. Manimekalan stated that species like Labeo dero, Puntius mudumaliensis, Schimatorhynchus nukta, Devario neilgherriensis, Crossocheilus latius latius, Clarias dayi and Gambusia affinis were restricted to the Moyar river system. Also, Clarias dayi, a critically endangered species, was recorded by Manimekalan and Arunachalam (2002). Puntius carnaticus and Danio aequipinnatus were recorded as common species of the Moyar river system. Rajan (1955) and Mukerjii (1931) both studied the headwaters of Bhavani River and reported that species like Travancoria elongata, Barilius canarensis, Rasbora caveri, Garra menoni and Silurus wynaadensis were restricted to the river system. Puntius filamentosus, Puntius melanampyx, Puntius carnaticus, Barilius gatensis, Danio aequipinnatus and Rasbora daniconius were very common in the Bhavani river system. Arunkumkar et al. (2015) recorded nearly 37 species from the Cauvery river system. Among several fish species, only Garra gotyla 
Table 4. Species composition among the 31 sites.

\begin{tabular}{lrl}
\hline $\begin{array}{l}\text { Cluster } \\
\text { no }\end{array}$ & $\begin{array}{r}\text { Cluster } \\
\text { consists of }\end{array}$ & Study sites \\
\hline 1 & $1-4$ & Thunakadavu stream, Baghapallam, Kallampalayam, Thunakadavu tunnel \\
2 & $5-7$ & Thenmudiparai, Orukomban range, Gulithuraipatti \\
3 & $8-28$ & $\begin{array}{l}\text { Melaparai, Valukuparai, Belemeenthurai, Anjurily, Oorpannikaham, Nellithurai, Belikoondu, Kadapilliyarthittu, } \\
\text { Sorrakottaodai, Puliyarkutti 3rd bridge, Mullaithodu, Kovaikutralam falls, Puliyarkutti 8th bridge, Sinnaru, }\end{array}$ \\
& & Nadathittu, Thonanthikla, Thellikal, Pillapara, Athirappilly, Noolpuzha, Ummikuppamthodu \\
4 & 29 & Naduthotam \\
5 & 30 & Thenkasithodu \\
6 & 31 & Urilikal \\
\hline
\end{tabular}

stenorhynchus, which is locally consumed, is recorded as being an endangered species in Grand Anicut Cauvery (Murthy et al., 2015). But Garra gotyla stenorhynchus is still under a status of least concern of the IUCN (International Union for Conservation of Nature).

Silas (1951), in his faunal account, discussed the extension of the range of Salmostoma acinaces (Chela argentea Day), Barbodes carnaticus (Barbus (Puntius) carnaticus), Osteochilus (Osteochilichthys) thomassi and Batasio travancoria and listed two endemic species described by Herre viz. Homoloptera Montana and Glyptothorax housei. Silas further reported five species from the Cochin part of the Anamalai Hills viz. Barilius bakeri, Puntius denisoni, Travancoria jonesi, Nemacheilus triangularis and Batasio travancoria. Puntius bimaculatus, earlier considered to be a juvenile of Puntius dorsalis, was collected from the Anamalai Hills. Interestingly this species is found to be the most dominant Puntius species in the hill ranges of the Eastern Ghats, especially the Javadi Hills. Puntius punctatus, earlier considered as a synonym of Puntius ticto, was kept as a separate species and both these species were collected from the Anamalai Hills (Menon, 1999).

The Periyar River originates near Moolavaigae and reaches the Mullaperiyar reservoir, located in the premises of Periyar Tiger Reserve, which is one of the most biodiversityrich zones in the southern Western Ghats (Silas, 1950, 1952; Kurup et al., 2004). Earliest studies on the fish fauna of the PTR date back to 1948, when Chacko (1948) listed 35 species from the Periyar Lake, including the critically endangered small-scale Schizothoracin Lepidopygopsis typus. Later, Menon and Devi (1995) described Hypselobarbus kurali from streams adjoining the Periyar River, raising the total number of fish species to 38 . In the present study, 64 species were collected from 31 study sites of six river systems of the southern Western Ghats. Species like Puntius melanampyx, Puntius carnaticus, Puntius amphibious, Puntius fasciatus, Puntius mahecola, Devario aequipinnatus, Garra mullya, Travancoria jonesi and Nemacheilus guentheri were commonly found in all of the six river systems (Fig. 7).

Smith and Smith (1990) stated that habitat selection of the fish fauna is influenced by the body structure, by food and shelter and by physiological processes. Moreover the fish adapt and respond to the characteristics of the rivers and streams, thereby helping the survival of the fittest. Hence it is reliable information that the micro- and macrohabitat play a key role in the morphology and physiological characteristics and modifications of the species. The fish prefer habitats where the nature of the river or stream substratum type is a muddy bottom with debris; this increases high species richness of the bottom feeders. Odum (1945) stated that the flow of the water in the channel is an important factor controlling the distribution of fish fauna; species like Barilius, Hypselobarbus, Puntius, Travancoria Rasbora and Tor prefer fast flow. The nature of the substratum and the flow rate seem to be more or less closely interrelated in governing the distribution of the fish fauna. This induces the dominance of the Cyprinid species to flourish well in all the river systems of the Southern Western Ghats. It is clear that ecological structure plays a key role in representing river systems of the southern Western Ghats, which has rich species diversity and abundance.

Conservation of India's vast and diverse aquatic genetic resources is essential to maintain ecological as well as socioeconomic equilibrium (Lakra et al., 2007). Fisheries and aquaculture have a promising role to play in social development by providing nutritional security for the Indian population and contributing to the economic advancement of farmers and fishery workers (Ambili, 2013). The concept of fish conservation is not new to India. Fishing was prohibited during the third Chatturmass (July-October) to protect the pre-spawning brood stock and juveniles. King Ashoka's prohibition period extended up to the middle of November. Renowned fisheries taxonomist Francis Day drew the attention of the government of India to the large-scale slaughter of fish and pleaded for urgent conservation measures. After persistent pressure, the Indian Fisheries Act was enacted in 1897. Destructive fishing methods, the creation of fixed engines (dams, weirs etc.) for catching fish and the use of small sized nets were banned by the law. The main threats impacting freshwater biodiversity in the Western Ghats include pollution (urban and domestic pollution ranking as the worst threats, followed by agricultural and industrial 


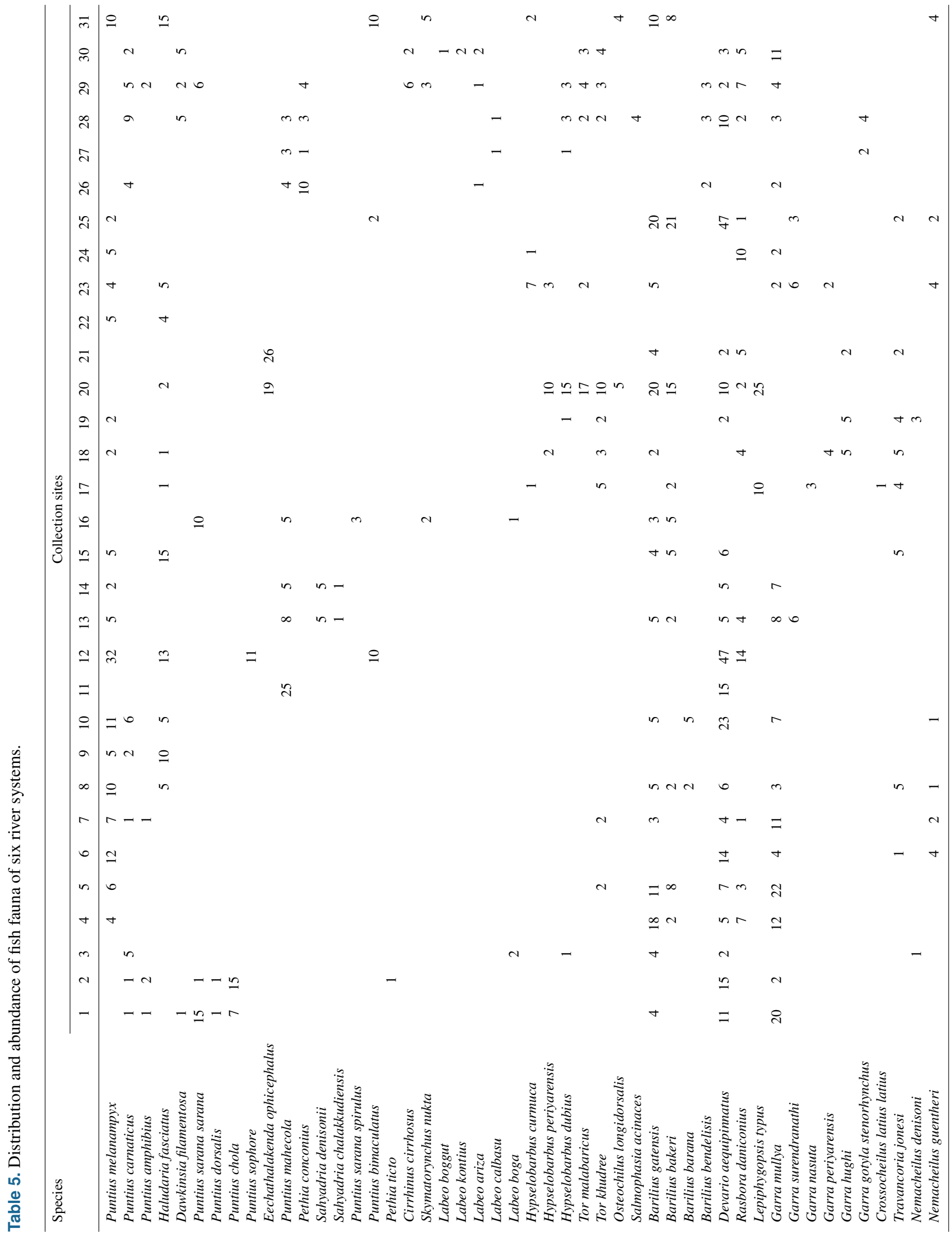




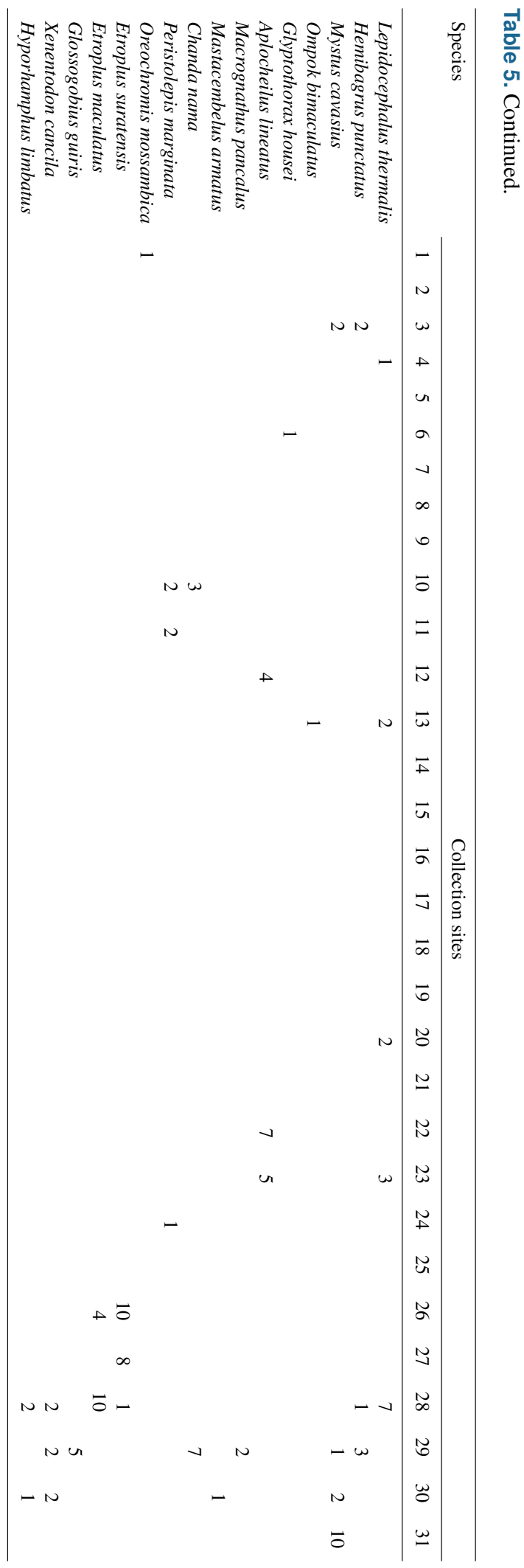

sources of pollution), residential and commercial development, dams and other natural system modifications, invasive species, agriculture and aquaculture and energy production and mining (IUCN, 2015). The anthropogenic perturbations to fresh water systems over the past years have escalated to enormous proportions, and it is estimated that about 3000 species will become extinct within the next 20 to 30 years (Das, 1994; Prasad, 2010).

The threat to the endangered fish species from our aquatic ecosystem can be minimized by employing both preventive and protective measures. The preventive measures may include removal of causative factors and provision of suitable legislation. The protective measures would include identification of suitable areas to declare as sanctuaries and the development of new technologies for the protection of the genetic resources of threatened and vulnerable fish species. Keeping this in view, the present investigation highlights some of the main causative factors of the decline of various fish species and some remedial measures for preserving the fish population. Degradation of aquatic systems, indiscriminate fishing of brood fish and juveniles, anthropogenic intervention, use of explosives and poisons and intrusion of exotic species are the major possible factors noticed in the present study which cause the depletion of fish population in the study area. Several authors have observed that a sharp decline in the fish population has been recorded in Indian rivers due to the indiscriminate fishing of brood stock and juveniles, fast degradation of aquatic ecosystems and the construction of dams, barrages, weirs, etc. Indiscriminate fishing of brood fish and juveniles and the use of explosives, poisons and electrocution are some of the major possible factors that cause the depletion of fish in Indian waters.

The indigenous fishermen have more preference towards fish species of large size and with medicinal properties. The use of different types of plant products by indigenous fishermen for fishing was observed, which kill all the fish fauna including juveniles. Croton tiglium L., Gnidia glauca (Fresen) Glig. Acacia intsia, Acacia torta and Hydnocarpus pentandra are some plants which can be used as fish poison for catching fish fauna. The parts of the plant (leaves, stem, bark, fruits and seeds) and the whole plants are used as fish poison. This method is only applicable in stagnant water, which leads to mass poisoning (Ambili, 2013). Dynamiting is another common practice seen among tribal people and it is frequently used in stagnant rock pools and deep waterbodies. In this method all the fish fauna available, from juveniles to adults, are affected on the spot. Dynamiting is also practised by tourists who visit these places illegally. The use of explosives, poisoning and electrocution and the use of small-sized nets etc. are some other fishing methods which affect the population adversely (Ambili, 2013). Use of copper sulfate is also a destructive method of fishing that leads to mass poisoning of the fish population. Irulas, Kurumbas and Mudugar are tribal settlements in the Attappadi region on the banks of Bhavani River. They use cast nets, gill nets 
Table 6. Water quality of 31 study sites of six river systems.

\begin{tabular}{|c|c|c|c|c|c|c|c|}
\hline Sampling locations & Altitude & $\mathrm{pH}$ & $\begin{array}{l}\text { Conductivity } \\
(\mathrm{mS})\end{array}$ & $\begin{array}{r}\text { TDS } \\
\left(\mathrm{mg} \mathrm{L}^{-1}\right)\end{array}$ & $\begin{array}{l}\text { Resistivity } \\
\qquad(\mathrm{K} \Omega)\end{array}$ & $\begin{array}{r}\text { DO } \\
\left(\mathrm{mg} \mathrm{L}^{-1}\right)\end{array}$ & $\begin{array}{l}\text { Water temperature } \\
\qquad\left({ }^{\circ} \mathrm{C}\right)\end{array}$ \\
\hline \multicolumn{8}{|l|}{ Moyar river system } \\
\hline Belemeenthurai & 520 & 8.4 & 59.2 & 37.7 & 16.4 & 1.3 & 24.5 \\
\hline Gulithuraipatti & 312 & 8.4 & 57.8 & 20.37 & 24.2 & 3.5 & 23.8 \\
\hline Kallampalayam & 300 & 7.9 & 45.2 & 28.5 & 21.9 & 2.5 & 24.1 \\
\hline \multicolumn{8}{|l|}{ Chalakudy river system } \\
\hline Urilikal & 3238 & 7.2 & 78.7 & 51.9 & 12.9 & 1.4 & 24.1 \\
\hline Thellikal & 840 & 8.8 & 59.2 & 37.7 & 16.4 & 1.3 & 24.5 \\
\hline Baghapallam & 748 & 8 & 57.8 & 38.0 & 16.8 & 2.4 & 21.7 \\
\hline Puliyarkutti 8th bridge & 527 & 7.79 & 27.8 & 18.0 & 34.8 & 5.4 & 23.5 \\
\hline Thunakadavu tunnel & 520 & 5.9 & 38.3 & 28.3 & 22.2 & 5.09 & 21.4 \\
\hline Puliyarkutti 3rd bridge & 512 & 7.79 & 27.8 & 18.0 & 34.8 & 5.4 & 23.5 \\
\hline Thunakadavu stream & 510 & 5.9 & 38.3 & 28.3 & 22.2 & 5.09 & 21.4 \\
\hline Thenmudiparai & 510 & 8 & 45.2 & 28.5 & 21.9 & 2.5 & 24.1 \\
\hline Orukomban range & 450 & 7.5 & 33.9 & 26.5 & 22.4 & 3.5 & 23.4 \\
\hline Pillapara & 267 & 7.6 & 34.0 & 19.5 & 29.9 & 0.89 & 33.6 \\
\hline Athirappilly & 202 & 7.2 & 35.2 & 47.5 & 3.97 & 0.73 & 32.7 \\
\hline \multicolumn{8}{|l|}{ Bhavani river system } \\
\hline Kovaikutralam falls & 560 & 7.5 & 31.3 & 20.1 & 32.3 & 3.2 & 22.5 \\
\hline Nellithurai & 380 & 7.3 & 30.3 & 20.3 & 31.5 & 2.3 & 25.5 \\
\hline \multicolumn{8}{|l|}{ Periyar river system } \\
\hline Melaparai & 965 & 9 & 44.7 & 28.8 & 22.5 & 1.3 & 26.1 \\
\hline Naduthotam & 950 & 7.5 & 46.2 & 30.4 & 20.6 & 0.7 & 25.9 \\
\hline Ummikuppamthodu & 943 & 7.7 & 64.9 & 43.2 & 17.1 & 1.2 & 24.8 \\
\hline Anjurily & 912 & 7.2 & 21.5 & 13.6 & 47.5 & 4.86 & 19.2 \\
\hline Oorpannikaham & 884 & 8.3 & 50.3 & 32.3 & 20.0 & 1.2 & 24.8 \\
\hline Sorrakottaodai & 879 & 8 & 34.2 & 21.9 & 29.5 & 1.1 & 23.1 \\
\hline Thenkasithodu & 872 & 5.2 & 22.0 & 13.7 & 45.6 & 6.11 & 18.9 \\
\hline Valukuparai & 869 & 7.7 & 66.9 & 43.8 & 15.1 & 0.7 & 24.8 \\
\hline Mullaithodu & 869 & 8.1 & 78.6 & 51.4 & 12.5 & 0.9 & 24.2 \\
\hline \multicolumn{8}{|l|}{ Cauvery river system } \\
\hline Kadapilliyarthittu & 1137 & 9.6 & 39.1 & 26.3 & 2.58 & 0.72 & 30.5 \\
\hline Thonanthikla & 341 & 9.2 & 39.5 & 26.3 & 2.65 & 3.11 & 30.2 \\
\hline Belikoondu & 267 & 9.4 & 39.8 & 26.3 & 2.63 & 0.63 & 32.7 \\
\hline Nadathittu & 262 & 9.4 & 39.8 & 26.3 & 2.63 & 0.63 & 32.7 \\
\hline Sinnaru & 225 & 9.2 & 39.5 & 26.3 & 2.65 & 3.11 & 30.2 \\
\hline \multicolumn{8}{|l|}{ Nugu river system } \\
\hline Noolpuzha & 2810 & 7.32 & 85.2 & 51.7 & 11.8 & 3.62 & 23.2 \\
\hline
\end{tabular}

and bamboo traps (Kooda) for fishing. Indiscriminate fishing in the Bharathappuzha caused a large decline in the Tor population (Ambili, 2013). Sarkar and Srivastava (2000) noticed that because of increased anthropogenic activities, the two main species, namely Tor putitora and Tor tor, are listed under the category of endangered species and face a high risk of extinction in the wild. Due to the proximity of human settlements, aquatic ecosystems are relatively more exposed to hu- man influences and interventions. In addition, the industrial and urban development has altered the aquatic environment (Ambili, 2013). Overfishing at various stages of the life cycle has been observed more in human settlement areas, and this causes spectacular changes in the environment that affect fishery resources. Pollution of the waterbody is also one of the main factors which cause the decline of the ichthyofaunal diversity (Ambili, 2013). 

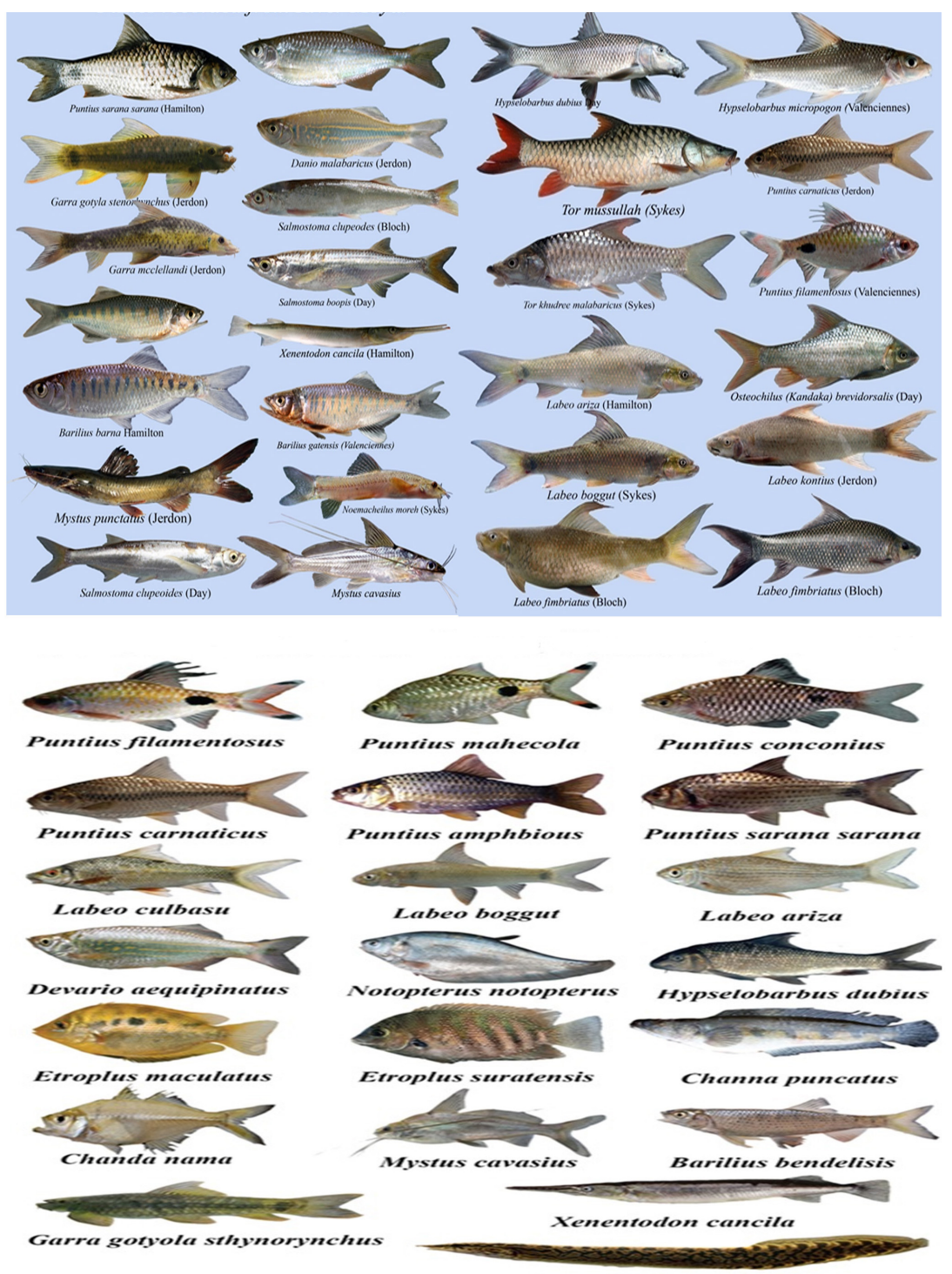

Macroganthus pancalus

(C) Dr. A. Manimekalan \& Dr. A. A. Arunkumar

Figure 7. Fish collected from various waterbodies of the southern Western Ghats.

The pristine riverine systems along the Western Ghats have been altered by anthropogenic activities such as dam constructions and road building, which have affected the ecology and habitat of these fish fauna. The tourist resorts starting down at Athirappilly on the bank of the Chalakudy River are altering the habitat in many ways. Sholayar Hydro Electric Project and Peringalkuthu Hydro Electric Project are the hydroelectric projects on the Chalakudy River. There are about seven dams built on the river. Peringalkuthu Dam in this river prevents the local migration of Tor from the lower to upper stretches of the river. There are 11 reservoirs in Bharathappuzha River, and Malampuzha Dam is the largest one. Neyyar Dam is located in the Neyyar River, and the
Idukki Dam is located in the Periyar River. The construction of dams also results in less water flow and affects the migration of fish. Food availability is an important factor for the existence of fish species. MacDonald (1948) noted that Mahseer (Tor) is an intermittent feeder. Vegetative matter, benthic diatoms, molluscan shells, crabs, insects, small fish fauna and different types of seeds and fruits have been recorded from the stomach contents of Tor species (Dinesh et al., 2010). The availability of these items varies considerably during different seasons. These disruptions in the food chain also affect the species adversely. The deforestation rate all along the Western Ghats is very high, and the forest areas are being transformed for agriculture practices. This was seen 
Table 7. Contribution of the variables (\%) after varimax rotation for habitat characteristics.

\begin{tabular}{lrr}
\hline Variables & D1 & D2 \\
\hline Altitude & 6.940 & 45.277 \\
pH & 0.849 & 0.147 \\
Conductivity $(\mathrm{mS})$ & 0.424 & 0.002 \\
TDS $(\mathrm{ppm})$ & 0.568 & 0.031 \\
Resistivity $(\mathrm{K} \Omega)$ & 0.715 & 0.075 \\
DO $\left(\mathrm{mg} \mathrm{L}^{-1}\right)$ & 0.900 & 0.180 \\
Salinity (ppt) & 0.923 & 0.196 \\
Water temperature $\left({ }^{\circ} \mathrm{C}\right)$ & 0.695 & 0.069 \\
Rubble and boulders & 0.676 & 0.060 \\
Gravel & 0.740 & 0.098 \\
Sand & 0.764 & 0.127 \\
Silt & 0.884 & 0.167 \\
Derbies & 0.828 & 0.120 \\
Bedrock & 0.714 & 0.037 \\
Stream order & 0.885 & 0.170 \\
Stream width $(\mathrm{m})$ & 0.819 & 0.155 \\
Stream depth $(\mathrm{m})$ & 0.909 & 0.196 \\
Area $\left(\mathrm{m}^{2}\right)$ & 21.449 & 20.245 \\
Volume $\left(\mathrm{m}^{3}\right)$ & 58.428 & 32.473 \\
Mean velocity $\left(\mathrm{m} \mathrm{s}^{-1}\right)$ & 0.891 & 0.177 \\
\hline
\end{tabular}

on the banks of most of the rivers in Kerala like Chaliyar, Sholayar, Chalakudy, Kabini, Bhavani, Periyar and Kallada river systems. Cultivation of Musa, paddy, cardamom, ginger and tea plantations is observed to be the most common. The pesticides used in these areas are penetrating the river systems and severely affect aquatic organisms like insects and diatoms, vegetation such as phytoplankton and even the small fish fauna (Ambili, 2013).

The fish population is declining rapidly among the streams and rivers of the southern Western Ghats. Hence the following immediate conservation measures will help to conserve these precious species. Awareness among the tribes is very important for the conservation of fish species. Awareness can be increased about the impact of using chemicals for mass poisoning, dynamiting for catching fish, fishing during breeding seasons and the use of poisonous plant products for mass poisoning. Students, social workers, fishermen and local people should be educated about the importance of conservation of fish fauna in their area so that they can create awareness among the people in the area. More exclusive projects should be started with the co-operation of local people and students to protect the fish population. Action can be taken to change the fishing profession of those who only depend on fishing for their livelihood, which will help to reduce the fishing pressure.

In order to conserve fish genetic resources and provide adequate living space, shelter and habitat for valuable threatened fish fauna, certain areas can be declared fish sanctuaries, like national parks and wildlife sanctuaries. Menon et al. (2000) suggested that suitable segments of the rivers with fish species should be identified for the establishment of fish sanctuaries and that such sanctuaries must be heavily stocked every year with fish fingerlings. There are two fish sanctuaries protecting the Tor species as part of the people's religious customs, Aruvikara (Neyyar River) and Kulathupuzha (Kallada) in Kerala. The upstream part of Chalakudy River, the Karimpuzha and Manjeeri region of Chaliyar River, a part of Bhavani up to Thavalam (Attappadi region) and selected stretches of Periyar River can be declared fish sanctuaries. Ambili et al. (2014) reported the presence of three species, Tor khudree, Tor malabaricus and Tor mussullah, in the Chaliyar River. Long stretches of Cauvery River are a fish sanctuary of which the Karnataka Forest Department (Wildlife) has leased out $22.5 \mathrm{~km}$. to the Wildlife Association of South India (WASI, 2018), Bangalore, Karnataka, which is now protecting the wildlife including fish fauna with more care.

Captive breeding is a technique widely used throughout the world for a variety of endangered animals including fish (Maitland and Evans, 1986; Keshavanath et al., 2006). It could be an important last resort measure for endangered and endemic species, which may otherwise become extinct in the wild (Reid, 1990). Fishery departments should take steps for the breeding and caring of the endangered Tor species. In Kerala, near Pookode Lake and Sholayar Dam, procedures for culturing the Tor species were attempted in hatcheries, but they did not succeed. Collection of matured brooders from the interior of the forest and maintenance of water temperature are the two major problems that were encountered. Now studies are going on to compensate the reasons for failures in Tor breeding. Gene banks can hold live animals or cryopreserved gametes. Gene banks can be considered as a last line of defence against species extinction. A live gene bank contributes to the delisting of threatened species by captive breeding and restocking in species-specific recovery programmes. Such gene banks can contribute to the recovery and utilization of genetic diversity and can be used in conservation programmes (e.g. NBFGR, India, and the World Fisheries Trust, Canada) and genetic enhancement (e.g. salmon in Norway and common carp in Hungary) (Lakra et al., 2007). A mini gene bank with the milt of T. putitora and T. khudree has been established by NBFGR (Ponniah et al., 1999a, b). In India Tor spermatozoa cryopreservation protocols have been developed by several workers (Basavaraja and Hedge, 2004, 2005; Patil and Lakra, 2005). Fish sperm cryopreservation requires the development of species-specific protocols (Lakra et al., 2006). Cryopreservation of germ plasm is a very good ex situ strategy to conserve existing allelic diversity for future use. This technique may also help to provide gametes for artificial propagation programmes in off seasons. Universities and research institutes should take care of the cryopreservation and captive breeding of Tor species. Reintroduction is more essential than introduction for the conservation of native species. Introduction can never neutralize 
the problem of the depletion of species, while reintroduction (collection and protection of wild/native fish fauna and their introduction into the rivers) can support the conservation of native species to a great extent. Introduction of Tor species in the rivers of Kerala from other regions or other river systems is causing more confusion and taxonomic ambiguities, and sometimes people wrongly quote this as evidence to support the Satpura Hypothesis (Kumar and Kurup, 2004).

The monitoring and documentation of fish stocks are becoming significantly important to carry out regular reviews of the distribution and status of all fish species, and this will be possible by maintaining records (Koljonen and Nyberg, 1991). The documentation of genetic resources for aquaculture is also a part of the coverage of the FishBase database (Froese and Pauly, 2013). The comprehensive listing of fish species' distribution as well as the continuous monitoring of fish species are a critical need for the protection of fish fauna.

\section{Data availability}

The data have been submitted in the Pangaea data bank and they can be accessed by the following link (https://doi.org/10.1594/PANGAEA.882214).

\section{Conclusion}

In the present study, from the fish fauna that were collected from various river systems of the southern Western Ghats, like Bhavani, Moyar, Chalakudy, Periyar, Cauvery and Kabini, it is noted that the order Cypriniformes was the most dominant order, with 3 families, 18 genera and 49 species $(76.6 \%)$, compared to other orders. Interestingly, sites like Thunakadavu stream, Gulithuraipatti, Athirappilly, Naduthotam, Nadathittu, Mullaithodu, Thonanthikla, Noolpuzha and Sinnaru revealed high species diversity. The results indicated that the species from the southern Western Ghats have an ambiguity in their taxonomy among the fishing communities. The data analyses suggested that species like $P$. melanampyx, $P$. carnaticus, $P$. amphibious, $P$. fasciatus and $P$. mahecola were found to be the dominant species in the locations considered. Among the 31 sites, maximum diversity $\left(H^{\prime}=1.268\right)$ was recorded at Sinnaru (altitude $=225$ ) of the Cauvery river system, and minimum diversity $\left(H^{\prime}=0.73\right)$ was recorded at Urilikal (altitude $=3238$ ) of the Chalakudy river system. The present findings support the Colinvaux theory, which expresses diversity changes with regards to elevation. The nature of the ecosystem and the vegetative forest which prevails along the river systems of the southern Western Ghats create suitable habitats for fish fauna. Many threats to the existence of fish fauna from the rivers of the southern Western Ghats, like the use of explosives and poison and the fishing of juveniles, are reported. Hence, urgent attention is necessary to create awareness among local communities of the importance of the stream habitat and its fish diversity, for the conservation of these important resources for future generations.

Author contributions. Both the authors have equally taken part in all aspects of the work and manuscript preparation.

Competing interests. The authors declare that they have no conflict of interest.

Acknowledgements. The authors gratefully acknowledge the University Grants Commission for providing the funding for this research, Tamil Nadu, Kerala and Karnataka forest departments for the permission and logistic support and the Department of Environmental Sciences, Biodiversity and Molecular Laboratory, Bharathiar University, Coimbatore, Tamil Nadu, India, for providing laboratory facilities for the research.

Edited by: Falk Huettmann

Reviewed by: two anonymous referees

\section{References}

Ambili, T. R.: Morphological and Molecular Characterization of Genus Tor from Southern Western Ghats, INDIA, PhD thesis, Dept. of Environmental Sciences, Bharathiar University, Coimbatore, September, 2013.

Ambili, T. R., Manimekalan, A., and Verma, M. S.: Genetic diversity of genus tor in river chaliyar, Southern Western Ghats, Kerala: through DNA barcoding, Journal of Science, 4, 206-214, 2014.

Anushiya, J. and Ramachandran, A.: Assessment of water availability in Chennai basin under present and future climate scenarios, in: Environmental Management of River Basin Ecosystems, edited by: Ramkumar, M., Kumaraswamy, K., and Mohanraj, R., Springer Earth System Sciences, Springer, Cham, 397415, 2015.

APHA: Standard methods, 19th edn., American Public Health Association Washington, DC, 1995.

Armantrout, N. B.: Aquatic habitat inventory, Bureau of Land Management, Eugene, District, USA, 32 pp., 1990.

Arunkumar, A. A. and Manimekalan, A.: Freshwater fauna and habitat characteristics of rivers in the Southern Western Ghats, India, PANGAEA, https://doi.org/10.1594/PANGAEA.882214 (last access: 24 September 2018), 2017.

Arunkumar, A. A., Manimekalan, A., Manikandan, V., and Velmurugan, P.: Fish species richness and habitat quality mapping with geographical information system across Cauvery River in Tamil Nadu, India, Journal of Aridland Agriculture, 1, 43-54, 2015.

Arunachalam, M., Madhusoodanan, K., Nair, C., Vijverberg, J., and Kortmulder, K.: Food and habitat partitioning among fishes in stream pools of South Indian River, International Journal of Ecology and Environmental Sciences, 23, 271-395, 1997.

Arunachalam, M., Sankaranaraysnan, A., Johnson, J. A., and Manimekalan, A.: Fishes of Nambiyar river, Kalakkad Mundan- 
thurai Tiger Reserve, Tamil Nadu, Journal of the Bombay Natural History Society, 97, 153-155, 2000.

Arunachalam, M., Sivakumar, P., and Muralitharan, M.: Habitat evaluation of pristine headwater streams of Western Ghat mountain ranges, Peninsular India, in: New trends in Fishery Development in India, edited by: Johal, M. S., Punjab University, India, 253-286, 2005.

Arunachalam, M., Muralidharan, M., and Sivakumar P.: Psilorhynchus amplicephalus, a new species from Balishwar river of Assam, India, Current Science, 92, 1352-1354, 2007

Basavaraja, N. and Hegde, S. N.: Cryopreservation of the endangered mahseer (Tor species of Mahseers. Tor. khudree, T. tor and T. putitora (Cyprinidae, Pisces)), Cytobios, 85, 205-218, 2004.

Basavaraja, N. B. and Hegde, S. N.: Some characteristics and short term preservation of spermatozoa of Deccan mahseer, Tor khudree (Sykes), Aquacult. Res., 36, 422-430, 2005

Biju, C. R., Raju Thomas, K., and Ajithkumar, C. R.: Fishes of Parambikulam wildlife sanctuary Palakkad District, Kerala, 1996.

BIS: Indian Standard Drinking Water - Specification, 2nd edn., Bureau of Indian Standards, New Delhi, 2012.

Chacko, P. I.: A survey of the fisheries of the Tungabhandra River, P. Indian Acad. Sci. B, 28, 166-175, 1948.

Colinvaux, P. A.: Ecology congress cataloging in publication data, 1930.

Dahanukar, N., Raut, R., and Bhat, A.: Distribution, endemism and threat status of freshwater fishes in the Western Ghats of India, J. Biogeogr., 31, 123-136, 2004.

Das, P.: Conservation and Management of cold water fish genetic resources, in: Coldwater, Aquaculture and Fisheries, edited by: Singh, H. R. and Lakra, W. S., Narendra Publishing House, Delhi, 337-339 1994.

Day, F.: On the fishes of Cochin, on the Malabar Coast of India. Part II. Anacanthini, P. Zool. Soc. Lond., 1, 286-318, 1865.

Day, F.: Monograph of Indian Cyprinidae. Parts 1-3, Journal of the Asiatic Society of Bengal., 40, 95-143, 1871.

Day, F.: The fishes of India; being a natural history of fishes known to inhabit the seas and fresh waters of India, Burma and Ceylon, 4th edn., New Delhi, 778 pp., 1878.

Dinesh, K., Nandeesha, M. C., Nautiyal, P., and Aiyappa, P.: Mahseers in India: A review with focus on conservation and management, Ind. J. Ani. Sci., 80, 26-38, 2010.

Gorman, O. T. and Karr, J. R.: Habitat structure and stream fish community, Ecology, 59, 507-515, 1978.

Gurumurthy, G. P. and Tripti, M.: Geochemical Perspectives on River Water of the Tropical Basins, Southwestern India, in: Environmental Management of River Basin Ecosystems, edited by: Ramkumar, M., Kumaraswamy, K., and Mohanraj, R., Springer Earth System Sciences, Springer, Cham, 329-353, 2015.

Hamilton, F.: An Account of the Fishes of River Ganges and its Branches, George Ramsay and Co., London, vii and 405 pp., 1822.

Hora, S. L.: Notes on fishes in the Indian Museum on a new species of Nemacheilus from the Nilgiri Hills, Records of the Indian Museum, 22, 19-21, 1921.

Hora, S. L.: Notes on fishes in the Indian Museum, on three collections of fish from Mysore and Coorg, South India, Records of the Indian Museum, 39, 5-28, 1937.
Hora, S. L.: Homalopterid fishes from Peninsular India, Records of the Indian Museum, XLIII, 211-232, 1941.

Hora, S. L.: Satpura hypothesis of the distribution of Malayan fauna and flora and flora of peninsular India, Proceedings of National Institute of Science of India, 15, 309-314, 1949.

Hora, S. L. and Misra, K. S.: Fish of Deolali, Part III, Journal of Bombay Natural History Society, 40, 20-38, 1938.

IUCN: https://www.iucn.org/ (last access: 24 August 2018), 2015.

Jayaram, K. C.: The Freshwater Fishes of the Indian Region, Nerendra Publishing House, New Delhi, 551 pp., 1999.

Jayaram, K. C.: The Freshwater Fishes of Indian Region, 2nd edn., Narendra Publications, New Delhi, 119 pp., 2010.

Jerdon, T. C.: On the freshwater fishes of southern India, Madras Journal of Literature and Science, 15, 141-149, 1848.

Keshavanath, P., Gangadhar, B., Basavaraja, N., and Nandeesha, M. C.: Artificial induction of ovulation in pond-raised mahseer, Tor khudree using carp pituitary and ovaprim, Asian Fish. Sci., 19, 411-422, 2006.

Kurup, B. M., Radhakrishnan, K. V., and Manojkumar, T. G.: Biodiversity status of fishes inhabiting rivers of Kerala (S. India) with special reference to endemism, threats and conservation measures, in: Proceedings of the Second Large Rivers Symposium, Phnom Penh, Kingdom of Cambodia, 11-14 February 2003, 163-182, 2004.

Lakra, W. S., Mohindra, V., and Lal, K. K.: Fish genetics and conservation research in India: status and perspectives, Fish Physiol. Biochem., 33, 475-487, https://doi.org/10.1007/s10695-0079168-z, 2007.

MacDonald, A.: Circumventing the Mahseer and other sporting fish of India and Burma, J. Bomb. Nat. Hist. Soc., 26, 306-307, 1948.

Maitlant, P. S. and Evans, D.: The role of captive breeding in conservation of fish species, International Zoo Yearbook, 24, 66-74, 1986.

Manimekalan, A.: Fishes of Mudumalai Wildlife Sanctuary, South India, Journal of Bombay Natural History Society, 95, 431-443, 1998.

Manimekalan, A. and Arunachalam, M.: Rediscovery of critically endangered air birthing cat fish Clarias dayi hora (Pisces: Claridae) from Mudumalai Wildlife Sanctuary, Tamil Nadu, Journal of Bombay Natural History Society, 99, 129-131, 2002.

Manimekalan, A. and Das, H. S.: Glyptothorax davissinghi (Pisces: Sisoridae) A new cat fish from Nilambur in the Nilgiri Biosphere, South India, Journal of Bombay Natural History Society, 95, 8791, 1998.

Manimekalan, A. and Singh, D. F.: New record of Schismatorhynchus (Nukta) nukta (Sykes) (Pisces: Cyprinidae) from Moyar river, extends its range to Tamil Nadu, Journal of Bombay Natural History Society, 94, 170-171, 1997.

Menon, A. G. K.: Check list - Fresh water fishes of India, Records of the Zoological Survey of India Occasional Papers, 175, 366 pp., 1999.

Menon, A. G. K. and Devi, K. Rema: Puntius sharmai, a new cyprinid fish from Madras, Journal of Bombay Natural History Society, 89, 353-354, 1992.

Menon, A. G. K. and Devi, K. Rema: Hypselobarbus kuali (pisces: Cyprinidae) a new large barb from the south western rives of peninsular India, Journal of Bombay Natural History Society, 92 , 389-393, 1995. 
Menon, A. G. K., Singh, H. R., and Kumar, N.: Coldwater Fish and Fisheries, in: Present eco-status of cold water fish and fisheries, edited by: Singh, H. R. and Lakra, W. S., Narendra Publishing House, New Delhi, 337 pp., 2000.

Mitchell, M. K. and Stapp, W. B.: Field Manual for Water Quality Monitoring: An Environmental Education Program for Schools, 6th edn., Thomson-Shore, 240 pp., 1992.

Mukerji, D. D.: On a small collection of fish from the Bhavani river (S. India), Journal of Bombay Natural History Society, 35, 162$171,1931$.

Murthy, K. R., Dhanakumar, S., Sundararaj, P., Mohanraj, R., and Kumaraswamy, K.: GIS-based modified SINTACS model for assessing groundwater vulnerability to pollution in Vellore District (Part of Palar River Basin), Tamil Nadu, India, Environmental Management of River Basin Ecosystems, 429-453, 2015.

Myers, N., Mittermeier, R. A., Mittermeier, C. G., da Fonseca, G. A. B., and Kent, J.: Biodiversity hotspots for conservation priorities, Nature, 403, 853-858, 2000.

Odum, H. T.: Primary production in flowing water, Limnol. Oceanogr., 1, 102-117, 1945.

Pielou, E. C.: Ecological Diversity, Wiley, New York, 1975.

Ponniah, A. G., Lakra, W. S., and Ogale, S. N.: Effects of cryoprotectants and fertilization protocol on viability of Mahseer, Tor khudree cryopreserved spermatozoa, Journal of Aquaculture in the Tropics, 14, 153-158, 1999a.

Ponniah, A. G., Sahoo, P. K., Dayal, R., and Bharat, A.: Cryopreservation of Tor putitora spermatozoa: Effect of extender composition, activating solution, cryoprotectants and equilibrium time, P. Natl. Acad. Sci. India, 69, 1-6, 1999 b.

Prasad, G.: Status and impacts of exotic fresh water fishes in Kerala, in: Conservation of Fishes in Kerala, India, edited by: Sonnenschein, L. and Benziger, A., World Aquarium and conservation for the ocean foundation, USA, 294 pp., 2010.

Rajan, S.: Notes on collection of fish from the headwaters of the Bhavani River, South IndiaJournal of Bombay Natural History Society, 53, 44-48, 1955.

Patil, R. and Lakra, W. S.: Effect of cryoprotectants, equilibration periods and freezing rates on cryopreservation of spermatozoa of mahseer, Tor khudree (Sykes) and T. putitora (Hamilton), Aquac. Res., 36, 1465-1472, 2005.
Reid, G. M.: Captive breeding for the conservation of cichlid fishes, J. Fish Biol., 37, 157-166, 1990.

Sarkar, U. K. and Srivastava, S. M.: Endangered Mahseer in North East India, in: Fish Biodiversity of North East India, edited by: Ponniah, A. G. and Sarkar, U. K., NBFGR, NATP publ, Lucknow, India, 95-96, 2000.

Shannon, C. E. and Weaver, W.: The mathematical theory of communications, Urbaba, University of Ilinois Press, Urbaba, 1949.

Silas, E. G.: On a collection of fish from Travancore, Journal of Bombay Natural History Society, 48, 792-795, 1950.

Silas, E. G.: On a collection of fish from the Annamalai and Nelliampathi hill ranges, Western Ghats, with a note on its zoogeographical significance, Journal of Bombay Natural History Society, XLIX, 470-481, 1951.

Silas, E. G.: Fishes from the high ranges of Travancore, Journal of Bombay Natural History Society, 50, 323-330, 1952.

Simpson, E. H.: Measurement of diversity, Nature, 163, 688, https://doi.org/10.1038/163688a0, 1949.

Smith, D. J. and Smith, C. R.: Summer bird species diversity and use of pastures by summer birds of the Finger Lakes National Forest, U.S. Dept. of Agric. Forest Service, Green Mountain National Forest, Final Project Report P.O. No. 40-1681-9- 0470, Middlebury, Vermont, 1990.

Southwood, T. R.: Ecological Methods, Chapmam and Hall, London, 1978.

Talwar, P. K. and Jhingran, A. G.: Inland fishes of India and adjacent countries, Oxford \& IBH Publishing Co. Pvt. Ltd, New Delhi, vol. I, 541 pp., 1991.

Thomas, J., Joseph, S., and Thrivikramji, K. P.: Hydrogeochemical drivers and processes controlling solute chemistry of two Mountain River basins of contrasting climates in the Southern Western Ghats, India, Environmental Management of River Basin Ecosystems, 355-396, 2015.

WASI: http://www.wasiindia.com/, last access: 24 August 2018.

Willis, S. C., Winemiller, K. O. and Fernandez, H. L.: Habitat structural complexity and morphological diversity of fish assemblages in a Neotropical floodplain river, Oecologia. 142: 284 - 295, 2005 . 